\title{
Heat shock proteins in the physiology and pathophysiology of epidermal keratinocytes
}

\author{
Dorota Scieglinska ${ }^{1}$ (1) • Zdzisław Krawczyk ${ }^{1}$ - Damian Robert Sojka ${ }^{1}$ - Agnieszka Gogler-Pigłowska ${ }^{1}$
}

Received: 8 July 2019 / Revised: 9 October 2019 / Accepted: 15 October 2019 / Published online: 16 November 2019

(C) The Author(s) 2019

\begin{abstract}
Heat shock proteins (HSPs), a large group of highly evolutionary conserved proteins, are considered to be main elements of the cellular proteoprotection system. HSPs are encoded by genes activated during the exposure of cells to proteotoxic factors, as well as by genes that are expressed constitutively under physiological conditions. HSPs, having properties of molecular chaperones, are involved in controlling/modulation of multiple cellular and physiological processes. In the presented review, we summarize the current knowledge on HSPs in the biology of epidermis, the outer skin layer composed of stratified squamous epithelium. This tissue has a vital barrier function preventing from dehydratation due to passive diffusion of water out of the skin, and protecting from infection and other environmental insults. We focused on HSPB1 (HSP27), HSPA1 (HSP70), HSPA2, and HSPC (HSP90), because only these HSPs have been studied in the context of physiology and pathophysiology of the epidermis. The analysis of literature data shows that HSPB1 plays a role in the regulation of final steps of keratinization; HSPA1 is involved in the cytoprotection, HSPA2 contributes to the early steps of keratinocyte differentiation, while HSPC is essential in the reepithelialization process. Since HSPs have diverse functions in various types of somatic tissues, in spite of multiple investigations, open questions still remain about detailed roles of a particular HSP isoform in the biology of epidermal keratinocytes.
\end{abstract}

Keywords Heat shock proteins - Epidermis - Keratinocytes - Cytoprotection - Epidermal homeostasis - Keratinocyte differentiation

\section{Introduction}

Heat shock proteins (HSPs) are principally referred to as molecular chaperones. Having diverse intracellular localization and functional differentiation, HSPs are involved in folding newly synthesized proteins, assembly of protein complexes, intracellular transport of proteins, or prevention of denaturation and/or unspecific aggregation of improperly folded proteins both under physiological and stress conditions. Through chaperoning multiple client proteins, HSPs participate in modulation of signal transduction including immunological responses, while by cooperation with the ubiquitination system,

Dorota Scieglinska and Zdzislaw Krawczyk contribute to this article equally as the first author

Dorota Scieglinska

dorota.scieglinska@io.gliwice.pl; onkologia@io.gliwice.pl

1 Center for Translational Research and Molecular Biology of Cancer, Maria Skłodowska-Curie Institute-Oncology Center Gliwice Branch, ul. Wybrzeże Armii Krajowej 15, 44-101 Gliwice, Poland participate in directing irreversibly damaged proteins into proteasomal degradation (Saibil 2013; Palotai et al. 2008). The research on HSPs in epidermal biology has been focused on investigating their functions in the context of physiological processes and also in response to different environmental stress conditions. It is noteworthy that epidermal keratinocytes, in contrast to other somatic cells, are unique in terms of expressing significant amounts of inducible HSPs constitutively, without previous stress challenge.

On the basis of molecular weight and amino acid (aa) sequence similarity, HSPs are subdivided into several families, namely HSPB (small HSP), HSPA (HSP70), DNAJ (HSP40), HSPC (HSP90), and HSPH (HSP110). The first name in the above list refers to the novel nomenclature system (Kampinga et al. 2009), which eliminates ambiguity in HSPs naming accepted by the HUGO Gene Nomenclature Committee (HGNC); the denotation in parenthesis conforms to common/historical names of the major HSP families (Lindquist and Craig 1988; Tóth et al. 2015).

The epidermis, the outermost layer of the vertebrate skin, is a squamous, stratified, non-vascularized cornified epithelium 
of ectodermal origin. This multilayered epithelium provides a barrier between the body and external environment, protecting mammals from dehydration, infection and environmental toxins. The major cellular component of epidermis are keratinocytes (around $90-95 \%$ of the epidermal cell population), which undergo a tightly controlled program of terminal differentiation. During this process, the undifferentiated keratinocytes from the basal layer (the innermost layer of the epidermis) permanently withdraw from the cell cycle, change their biological activity and morphology, and move suprabasally to form stratum spinosum, stratum granulosum and stratum corneum. The outermost epidermal layer consists of dead, flattened, non-nucleated keratinocytes termed corneocytes. This is the essential structure of the epidermal barrier.

Human epidermis follows a tightly regulated proliferation and differentiation program with an interplay between stem cell self-renewal and differentiation in order to maintain tissue homeostasis (Fig. 1). Despite decades of skin research, regulation of homeostasis in human epidermis is still insufficiently understood and remains a matter of debate. In particular, the data are insufficient to convincingly determine the cell dynamic in interfollicular epidermis in human skin. Significant amount of data comes from studies conducted on the interfollicular epidermis of mouse skin. Despite evident differences between mouse and human epidermis with respect to stratification and thickness, it is believed that the basic maintenance mechanism of epidermal homeostasis might be quite similar in human and mouse, as many conclusions derived from studying epithelial biology in mouse or rat models are considered relevant also to human tissue. Since the work of Potten (1974), the long-held concept of epidermal proliferative units (EPUs) postulated that self-renewal of the epidermis is dependent on slow-cycling, long-lived, and self-renewing keratinocyte stem cells which constitute $1-10 \%$ cells of the basal layer and undergo asymmetric divisions giving rise to one long-lived stem cell and the other, short-living one called transit amplifying cell (TA). TA cells were supposed to divide mitotically several times before undergoing terminal differentiation. The model postulated that epidermis is composed of EPU each having a columnar shape perpendicularly oriented from the basal membrane to the top of the cornified layer and containing basally located one stem cell surrounded by approximately ten TA cells and their maturing progeny located suprabasally (Strachan and Ghadially 2008; Senoo 2013).

Advances in cell tracing analysis caused the EPU model to be questioned, and currently, alternative ideas were proposed to explain the maintenance of epidermal homeostasis (reviewed in Gonzalez-Celeiro et al. 2016). Among them, the hierarchical model assumes that the basal layer contains slow-cycling long-term stem cells (SCs) that in turn give rise to fast-dividing cells termed "committed progenitors." Another concept, called a regional specificity model, postulates that slow-cycling and fast-cycling stem cells co-exist, but they occupy and maintain different domains in the epidermis. The last but not least stochastic choice model assumes that all
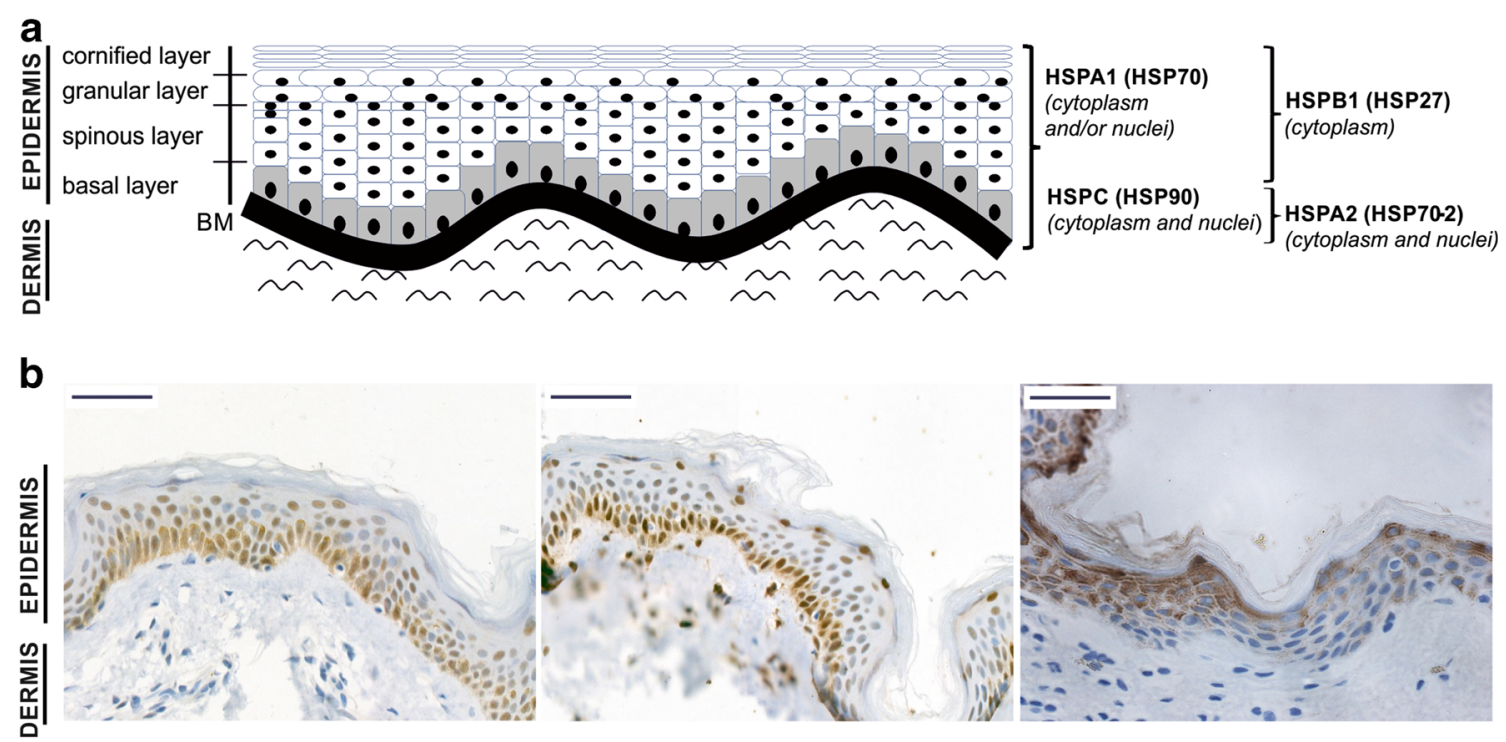

Fig. 1 Differential expression of HSPs in human epidermis. a Schematic representation of HSPC (HSP90), HSPA1 (HSP70), HSPA2, and HSPB1 (HSP27) location based on the results of numerous works cited in this review article. b Location of the HSPB1, HSPA1, and HSPA2 proteins in human skin. Microphotographs showing examples of DAB-mediated immunohistochemical staining in formalin-fixed and paraffin-embedded human skin. The skin sections were incubated overnight with primary antibodies: mouse monoclonal anti-HSPB1 (Novocastra, 1:40); mouse monoclonal anti-HSPA1 (Enzo Life Science; 1:300); rabbit monoclonal anti-HSPA2 (Abcam, 1:6000). The bar represents $50 \mu \mathrm{M}$ 
basal cells are equivalent in terms of their potential to divide or differentiate. The critical belief in all these models is that the progenitor cells divide asymmetrically. This mechanism allows for generation of sibling cells that adopt distinct fate decision - one of them remains progenitor cell while the other one is committed into differentiation. Alternatively, symmetric division of progenitors can also give rise either to two progenitors or two post-mitotic differentiating cells; however, such scenarios are likely to happen less frequently than asymmetric divisions (Gonzalez-Celeiro et al. 2016). Thus, it is postulated that the homeostasis of interfolicular epidermis is maintained by fast-dividing progenitor cells. In turn, a small fraction of slow-cycling multipotent/pluripotent stem cells, which is clustered around the hair follicles, or placed under the edges of the overlying scales in the hairless skin of rodents tail, is likely responsible for the wound healing and regenerative processes, but make marginal contribution to epidermal homeostasis (Doupe and Jones 2012; Alcolea and Jones 2014; Mascré et al. 2012). Essentially, it seems accepted that the basal layer of the interfolicular epidermis has heterogeneous composition and contains progenitors cells, post-mitotic cells, and a small fraction of stem cells.

Keratinocytes are also responsible for restoring the epidermis after cutaneous injury. Re-epithelialization, one of the early steps of multistage wound healing process, is a temporal reprogramming of the phenotype of keratinocytes in the basal layer toward migratory state characterized by high ability to migrate laterally into the wound over the denuded area. This phenotypic switch manifests by a loss of the extracellular matrix-cell and cell-cell contacts and acquisition of capability to interact with a provisional extracellular matrix formed by proteins of the clot. During migration, keratinocytes restrain their proliferation, albeit divisions can be restored when the first layer of keratinocytes covers the wound (Gonzalez et al. 2016). These tightly coordinated processes ensure epidermal homeostasis re-establishment of injured skin. Keratinocyte proliferation and migration are crucial steps for the rapid closure of the epidermis during wound healing, but the molecular mechanisms involved in this cellular response remain to be completely elucidated.

Considering pleiotropic roles of HSPs, both under physiological and stress conditions, in this review, we summarized current knowledge of HSPA1 (HSP70), HSPA2, HSPB1 (HSP27), and HSPC (HSP90) in keratinocyte biology. Of all HSPs, the above-mentioned proteins have been the most intensively investigated ones in the context of epidermal homeostasis. Here, we discuss their involvement in keratinocyte cytoprotection, epidermal differentiation, and wound healing. Some aspects concerning implications of HSPs in plastic surgery, dermatology, skin aging, and immunotherapy of skin cancer have been discussed in earlier reviews (Morris 2002; Jonak et al. 2006; Wagstaff et al. 2007; Vidal Magalhaes et al. 2012).

\section{Essentials about the HSPB1 protein, a member of the HSPB multigene family encoding low molecular weight (12-43 kDa) HSP proteins}

The HSPB family contains several members of which some are expressed ubiquitously, and others in a cell-type specific fashion (Arrigo 2017). Among several members of the human HSPB family, only HSPB1 (historical names: HSP27 in human, HSP25 in rodents) has been investigated in the context of keratinocyte biology. HSPB1 is a stress-inducible chaperone, which having so called holdase activity participates in transferring unfolded peptides to HSPA-HSPC-HSPH chaperone machinery supporting them to achieve native structures and preventing from unspecific aggregation (reviewed in: Hilton et al. 2013; Treweek et al. 2014). Structural modifications of HSPB1 that comprise oligomerization and specific phosphorylation pattern are considered critical for regulating its interaction with specific clients and shaping its cell typeand condition-specific functions (Arrigo 2013). Under cellular stress, some protein pool of HSPB1 migrates from cytoplasm into the nucleus (Bryantsev et al. 2007), and/or can be secreted outside the cell (Pockley et al. 2014). HSPB1, considered one of the most important elements of cellular proteostasis, is functionally involved in numerous physiological processes and can be also engaged in sustaining pathological states (Kampinga and Garrido 2012). HSPB1 is usually overexpressed in various tumors and cancer cell lines. Depending on the tumor type, its elevated expression was associated with either good or bad prognosis, or did not show prognostic value (Kaigorodova and Bogatyuk 2014).

\section{Expression of HSPB1 in normal epidermis and pathological epidermal lesions}

Presence of the HSPB1 protein in keratinocytes positioned in the suprabasal layers of healthy human epidermis was revealed by immunohistochemical (IHC) studies (GandourEdwards et al. 1994; Trautinger et al. 1995a). Similar expression pattern was observed in normal murine epidermis, albeit Laplante et al. (1998) noted absence of HSPB1 in stratum corneum, while Crowe et al. (2013) showed its preferential location in this layer. Selective or predominant presence of HSPB1 in upper epidermal layers, specifically in the granular one, was confirmed in tissue-engineered skin reconstructed from either human or rat keratinocytes (Robitaille et al. 2010; Jonak et al. 2011; O'Shaughnessy et al. 2007). Colocalization studies revealed that in terminally differentiated keratinocytes, HSPB1 was a component of peripherally located multiprotein complexes comprising among others loricrin and filaggrin, key proteins engaged in the cornification process (Jonak et al. 2002). IHC studies showed that transient heat shock (HS) induced both HSPB1 expression and its 
translocation from cytoplasm into the nucleus in normal human epidermal keratinocytes (NHEK) and HaCaT cells in vitro (McClaren and Isseroff 1994), and in locally heated areas of human buttock skin in vivo (Wilson et al. 2000). Interestingly, HSPB1 expression was also shown to be activated in human skin explants by freezing stress (Jeanmaire et al. 2003).

The expression of HSPB1 was also analyzed in developing epidermis during embryonal development in human and mice (Jantschitsch et al. 1998; Monastirli et al. 2005; Duverger and Morange 2005; O'Shaughnessy et al. 2007). Comparing HSPB1 expression in the embryonal epidermis of mouse and human, one may notice that in the latter case, this protein is absent in the single-layered primitive epidermis and its synthesis starts along with activation of differentiation process. Also, HSPB1 shows uniform cytoplasmic distribution in human keratinocytes, while in murine cells, it localizes in cytoplasmic spots.

Altered expression of HSPB1 was observed in various pathological skin conditions. Its decreased level was detected in cutaneous squamous cell carcinoma (SCC) (GandourEdwards et al. 1994; Trautinger et al. 1995a), in UV-induced murine skin SCC tumors (Kiriyama et al. 2001), and in human epidermoid carcinoma A431 cells (Kindas-Mugge et al. 1996). Significant reduction in HSPB1 expression was observed in some rare skin diseases such as bullous ichthyosiform erythroderma and annular epidermolytic ichthyosis, and was not detected in keratinocytes derived from lesional skin of some patients with X-linked recessive ichthyosis, congenital hemidysplasia with ichthyosiform nevus, and limb defects syndrome. In turn, the pattern of HSPB1 expression was similar to healthy skin in other than abovementioned hereditary cases of ichthyosis (Jonak et al. 2005), as well as in non-cancerous skin lesions such as actinic keratosis, seborrhoeic keratosis, solar keratosis, and human papillomavirus-induced keratinocyte hyperproliferation (Trautinger et al. 1995a; Gandour-Edwards et al. 1994). In contrast, keratinocytes in inflammatory skin diseases such as psoriasis (Boehncke et al. 1994; Choi et al. 2012) and atopic dermatitis (AD) (Niiyama et al. 2016) were found to contain significantly higher levels of HSPB1 than keratinocytes of healthy skin. However, no essential changes in HSPB1 expression between keratinocytes of $\mathrm{AD}$ and healthy skin were reported by others (Ghoreishi 2000).

Interesting link between HSPB1 and psoriasis emerged from studies aimed at analyzing the phenotype of cells deficient in the DNAJA3 (TID) protein, one of the members of numerous DNAJ (HSP40) family. It was found that TID-1s, the shortest splicing form of DNAJA3, when complexed with MK5 kinase, inhibited HSPB1 phosphorylation and negatively affected polymerization of F-actin in HeLa cells. Oppositely to HeLa cells, psoriatic keratinocytes were negative for TID-1s and contained increased levels of phosphorylated HSPB1. In HaCaT cells, increasing TID-1s levels interfered with TNF- $\alpha$ induced phosphorylation of HSPB1 and polymerization of F-actin, as well as inhibited TNF-stimulated cell migration. These results suggested that the loss of the TID-1s is one of factors responsible for the development of psoriasis via mechanism partially related to enhanced phosphorylation of HSPB1 (Choi et al. 2012). Another study suggested HSPB1 to be among autoantigens of a streptococcal-induced autoimmune response, being one of the targets of the exaggerated $\mathrm{T}$ cell response in psoriasis (Besgen et al. 2010).

\section{The role of HSPB1 in regulating keratinocyte differentiation in adult epidermis}

The pattern of HSPB1 expression in epidermis implied participation of this chaperone in the late stages of keratinocyte differentiation. One of well-known regulator of keratinocyte differentiation is calcium ions $\left(\mathrm{Ca}^{2+}\right)$ (Elsholz et al. 2014). Low $\mathrm{Ca}^{2+}$ levels $(0.03-0.05 \mathrm{mM})$ in media maintain basallike phenotype of keratinocytes, while higher $\mathrm{Ca}^{2+}$ levels (0.5-1.2 $\mathrm{mM})$ activate differentiation process. Early studies showed that HSPB1 was barely detectable in NHEK grown in low $\mathrm{Ca}^{2+}$ media, whereas a switch to high $\mathrm{Ca}^{2+}$ concentration significantly raised the intracellular level of HSPB1 and increased subpopulation of HSPB1-positive keratinocytes (Kindas-Mugge and Trautinger 1994). $\mathrm{Ca}^{2+}$-mediated increase in HSPB1 expression was confirmed in studies performed on human $\mathrm{HaCaT}$ (Arrigo and Ducasse 2002), and murine PAM212 cells (Duverger et al. 2004). Increased levels of HSPB1 in NHEK were also found during differentiation induced in vitro by high cell confluency, or treatment with calcium ionophore A23187, as well as during formation of granular layer in reconstructed epidermis (Robitaille et al. 2010).

HSPB1 underdoes phosphorylation and forms aggregates in the cytoplasm and nuclei of differentiating keratinocytes. The p38 mitogen-activated protein kinases (p38 MAPK) signaling cascade represent one of pathways engaged in HSPB1 phosphorylation (Duverger et al. 2004; Jonak et al. 2011). Inhibition of p38-MAPK signaling prevented $\mathrm{Ca}^{2+}$-induced terminal differentiation of NHEK simultaneously blocking phosphorylation of HSPB1. Similarly, inhibition of p38MAPK paralleled the phenotypic effects of RNAi-mediated knockdown of HSPB1 in reconstructed epidermis model; both treatments caused aberrant stratification. Thus, p38-MAPKmediated phosphorylation of HSPB1 is vital for keratinocyte differentiation and formation of regularly stratified epidermis (Jonak et al. 2011).

In keratinocytes, HSPB1 can undergo phosphorylation also by Dual Leucine zipper-bearing Kinase (DLK), an upstream activator of the MAP kinase pathways (Robitaille et al. 2005). Adenoviral-mediated overexpression of DLK in NHEK 
caused relocation of a fraction of HSPB1 into insoluble cytoskeletal complexes during formation of cornified envelope, but had no effect on a total level of the protein. In turn, siRNA-mediated knockdown of HSPB 1 in DLKoverexpressing $\mathrm{HaCaT}$ cells interfered with involucrin expression, suggesting a potential role for HSPB1 and DLK in regulating involucrin stability and/or expression. It seems that DLK affects functional properties of HSPB1 not by itself, but rather via activation of ERK kinase responsible for phosphorylation and cytoskeletal redistribution of HSPB1. DLK also activates JNK pathway capable to counteract HSPB1 phosphorylation by reducing ERK activity (Robitaille et al. 2010). Recently, RHE model-based study revealed that DLK1 promotes peripheral localization of HSPB1, as well as LIS1, a protein involved in cortical organization of microtubules in differentiating keratinocytes (Simard-Bisson et al. 2017).

Yet, another kinase known to play an essential role in regulating HSPB1 functionality is AKT. Double knockout of $A K T 1$ and $A K T 2$ genes in mouse caused early postnatal lethality and a serious cutaneous defect manifested by a lack of stratum corneum. In contrast, mice with single knockdown of either $A K T 1$ or $A K T 2$ were viable and had phenotypically normal skin showing only subtle disturbances in the formation of cornified envelope. Their epidermis contained significantly reduced levels of phosphorylated HSPB1, what suggested that both kinases contribute to posttranslational modification of this chaperone in keratinocytes. What is more, AKT1dependent phosphorylation of HSPB1 seems to promote its binding to filaggrin, filaggrin maturation, and development of stratum corneum (O'Shaughnessy et al. 2007). Further study showed AKT1 activity to be important for switching HSPB1 function from actin stabilization to filaggrin processing (Gutowska-Owsiak et al. 2018). Altogether, the above results indicated that AKT1-dependent modulation of HSPB1 activity may be vital for cornification and formation of a fully functional skin barrier. Surprisingly, study of HSPB $1^{\text {del/del }}$ mice showed that HSPB1 is dispensable for normal development and maintenance of the unwounded epidermis in vivo (Huang et al. 2007; Crowe et al. 2013). It turned out, however, that HSPB1 is required for wound healing process since the phenotypic alterations in knockout mice manifested after skin wounding and comprised reduced re-epithelialization and increased inflammation (Crowe et al. 2013).

\section{The influence of UV light and chemical irritants on HSPB1 expression in keratinocytes}

Epidermal keratinocytes, being frequently exposed to elevated temperature, are also commonly subjected to sun's ultraviolet radiation (UV) which consists mostly (96-99\%) of long wave ultraviolet (UVA; $320-400 \mathrm{~nm}$ ), and to less extent (1-6\%) of short wave ultraviolet (UVB; 290-320 nm). While UVA can reach dermis, UVB is almost completely absorbed by the epidermis, and constitutes a main environmental factor damaging keratinocyte DNA. UVC (100-290 nm), the third component of solar radiation, is entirely absorbed by the atmosphere; thus, no significant irradiation of the skin results from natural sources. Most harmful effect of phototoxicity is a development of skin cancer (reviewed in: D'Orazio et al. 2013; Kim et al. 2015).

Transcriptomic studies indicated HSPB1 mRNA as one of seven protein coding sequences, expression of which increased at least threefold after exposure of human keratinocytes to UVB in vitro (Becker et al. 2001). UVinduced expression of HSPB1 was also observed in NHEK cells irradiated with the UVB dose equivalent to sun exposure causing mild skin redness in people with light complexion (Wong et al. 2000), and in human skin ex vivo model exposed to radiation mimicking solar light (Jeanmaire et al. 2003). Irradiation of dorsal skin of female hairless mice or PAM212 keratinocytes with physiologically relevant doses of UVB induced nuclear and/or perinuclear accumulation of HSPB1 and stimulated its phosphorylation (Nozaki et al. 1997). Similar pattern was observed in human keratinocytes, and in this case, UVB-induced phosphorylation of HSPB1 was executed by p38 MAPK signaling cascade possibly via generation of reactive oxygen species (Wong et al. 2000). Studies performed on telomerase-immortalized keratinocytes revealed that solar UV or equivalent dose of UVB significantly increased the level of phosphorylated HSPB1 and led to activation of $\mathrm{p} 38 \alpha$ and MSK2 kinases, at the same time decreasing the activity of ERK kinases and having minimal impact on several other variants of p38 kinase (p38ß, p38 $\gamma$ and p38 ). In contrast, UVA had minimal effect on both HSPB1 phosphorylation and activity of kinase signaling pathways. These results confirmed that the key signaling pathway activated by both solar and UVB radiation is dependent on $\mathrm{p} 38 \alpha$ kinase activity, and that this pathway plays a key role in HSPB1 phosphorylation (Liu et al. 2013).

Because harmful environmental hazards such as HS or UV have a clear impact on the HSPB1 expression and its posttranslational modifications, a number of studies were undertaken to assess whether HSPB1 could be useful as a marker for identification of skin irritants related to occupational or environmental exposure, or present in cosmetic products. Given that due to EU regulations, cosmetic testing in animal models is banned, the toxicity tests are conducted in vitro, on keratinocytes growing either in 2D monolayer or 3D organotypic culture. Proteomic analysis revealed that HSPB1 is among several proteins upregulated in human epidermis (Boxman et al. 2002b; Chen et al. 2014), or primary foreskin keratinocytes (Zhang et al. 2011) exposed to sodium lauryl sulfate (SLS), a surfactant widely used for inducing the experimental contact dermatitis. Increase in HSPB1 expression was also reported in $\mathrm{HaCaT}$ cells exposed to heavy metals 
(potassium dichromate, neodymium nitrate), or sodium dodecyl sulfate (SDS), contaminants of cosmetic products that may cause inflammatory skin conditions such as eczema, lichenoid, or vasculitis (Zhang et al. 2010). Higher levels of HSPB1 were found in keratinocytes exposed to mustard gas or its derivatives (2-chloroethyl ethyl sulfide; CEES) (Mol et al. 2008; Black et al. 2011), to ozone $\left(\mathrm{O}_{3}\right)$ (Valacchi et al. 2002, 2003), and to exhaust gas or cigarette smoke (Jeanmaire et al. 2003). Also parabens, a class of preserving additives found in cosmetics that can cause skin irritation and contact dermatitis, elevated the levels of HSPB1 in skin equivalents (Ishiwatari et al. 2007). Similar findings were reported in the epidermis of bitumen exposed workers, and notably, HSPB1 was found in all epidermal layers including the basal one (Fenga et al. 2000). Interestingly, HSPB1 expression was not changed by mechanical skin irritation caused by type stripping; this observation may indicate that HSPB1 should not be regarded as a universal marker of skin irritation (Dickel et al. 2010).

\section{HSPB1 as cytoprotective and immunomodulatory factor}

HSPB1 is classified as a molecular chaperone; thus, one could assume that its increased expression in keratinocytes exposed to cytotoxic factors may reflect activation of an adaptive response. Systematic study that would unambiguously demonstrate protective function of HSPB1, however, has not been performed so far. Some premise was provided by study on A431 skin cancer cells transfected with vector encoding the human HSPB1 gene. After transfection, the cells became slightly more resistant to HS, but their sensitivity to UVA, UVB, or hydrogen peroxide remained unaffected (Trautinger et al. 1997). Recent studies on mice showed that the inactivation of HSPB1 (as well as HSPA1) in vivo by locally administrated antibodies reduced the incidence of neoplastic lesions in the skin treated with 7,12-dimethylbenzene(a)anthracene (DMBA) and benzo(a)pyrene (Yusuf et al. 2015). It is worth noting that the translocation of HSPB1 into the keratinocytes nuclei following stress (treatment with SLS or UV) can be modulated by antioxidants (vitamin C) (Boxman et al. 2002a).

HSPB1 may also play a role in regulating inflammatory pathways in the epidermis. The depletion of HSPB 1 in keratinocytes through siRNA-mediated gene silencing stimulated production of PGE2 both in the control and TNF- $\alpha$ activated cells, as well as release of IL- $1 \alpha$, IL- 8 upon UVB irradiation or TNF- $\alpha$ stimuli. Moreover, HSPB1 can differentially influence synthesis of proinflammatory cytokines in keratinocytes and dermal fibroblasts (DFs) - suppressing the process in keratinocytes while activating in DFs (Sur et al. 2008).

\section{Essentials about the HSPA1, a member of the conservative HSPA (HSP70) family}

The HSPA1 is one of the most thoroughly investigated HSinducible chaperone (Radons 2016). The human genome contains two intronless HSPA1 genes localized within the MHC III region, namely HSPA1A and HSPA1B, which share $99 \%$ nucleotide sequence similarity in the protein coding region. Encoded proteins differ only by two aa, thus are considered functionally equal. Generally, HSPA1 is weakly expressed (if at all) in somatic cells under physiological conditions, but its levels can be highly elevated by HS and other environmental stresses as well as under various pathological conditions, particularly in tumors (Calderwood 2018). However, it is known that HSPA1 can be produced constitutively at relatively high levels in certain somatic cell types (Scieglinska et al. 2011). The stress-induced expression of HSPA1 is a transcriptional response initiated via binding of a heat shock transcription factor 1 (HSF1) to the promoter regulatory sequence called heat shock element (HSE). Upon stress a significant fraction of HSPA1, protein translocates from the cytoplasm into the nucleus and nucleoli (Pelham 1984). HSPA1, in cooperation with several other HSPs and co-chaperones, plays a critical cytoprotective role enabling survival of stressed cells (Radons 2016). Molecular stresses or pathophysiological conditions can also stimulate relocation of HSPA1 into extracellular space or/and onto the plasma membrane. Such responses contribute to the modulation of immune processes (both innate and adaptive) and inflammation (Multhoff and Hightower 2011; Calderwood et al. 2016).

The general features of HSPA1 are relatively well established; however, there are some problems in analyzing the literature data, namely inconsistency in the HSPAs nomenclature, and discrepancies related to results of HSPA1 immunodetection due to poor specificity of anti-HSPA1 antibodies. The second issue seems extremely disturbing because it is well known that even frequently used commercial antibodies may cross-react with different highly homologous members of the HSPA family (Malusecka et al. 2006; Chow et al. 2010; Scieglinska et al. 2011).

\section{Expression of HSPA1 in the normal skin}

The earliest studies based on radioactive protein-labelling techniques (Deaton et al. 1990; Edwards et al. 1991; Maytin et al. 1990), as well as further research performed using more advanced methodology (e.g., IHC, western blotting, mass spectroscopy), revealed that at physiological temperature, the stress-inducible HSPA1 protein is constitutively present in isolated keratinocytes and $\mathrm{HaCaT}$ cells, and it localizes mainly in the cytoplasm (Schmidt-Rose et al. 1999; Lamore et al. 2010; Perluigi et al. 2010; Parat et al. 1998; Evdonin 
et al. 2006; Nakamura et al. 2010; Prado et al. 2011; Hintzsche et al. 2012; Ramirez et al. 2015).

Initial IHC studies performed on human skin explants generated inconsistent results showing either no HSPA1-positive reaction both in the epidermis and dermis (Muramatsu et al. 1992), low intensity staining in epidermal keratinocytes (Wilson et al. 2000; Boyman et al. 2005), or very strong staining selectively in the epidermis (Trautinger et al. 1993; Curry et al. 2003). These discrepancies in the expression pattern are thought to result from the use of anti-HSPA1 antibodies of poor or unverified specificity. Most recent IHC studies that ensured satisfactory specificity of the antigen detection confirmed constitutive, cytoplasmic/ nuclear presence of HSPA1 in non-stressed keratinocytes in all epidermal layers, but not in the dermis (Scieglinska et al. 2011; Wang et al. 2011; Kleszczyński et al. 2015; Murase et al. 2016). Interestingly, keratinocytes in African Americans contained more HSPA1 than those in White Americans, what might implicate that HSPA1 in keratinocytes prevents the degradation of melanosomes after their transfer from melanocytes (Murase et al. 2016). Constitutive expression of the HSPA1 protein in epidermal keratinocytes was also found in rodents in vitro (Quenneville et al. 2002; Matsuda et al. 2010) and in vivo, albeit in contrast to humans preferentially in the upper epidermal layers (Laplante et al. 1998; Keagle et al. 2001; Souil et al. 2001).

The basal level (non-induced by stress) of HSPA1 expression in keratinocytes was suggested to depend on differentiation stage, but still it is unknown whether the protein is causally involved in the differentiation process. HSPA1 level was found relatively low in NHEK (3rd-passage) and $\mathrm{HaCaT}$ cells grown in low $\mathrm{Ca}^{2+}$ medium, but it was higher in high $\mathrm{Ca}^{2+}$ medium (Wakita et al. 1994; Orel et al. 1997). Interestingly, $\mathrm{Ca}^{2+}$-induced increase in HSPA1 expression could be suppressed by interaction of $\alpha$-melanocyte stimulating hormone $(\alpha \mathrm{MSH})$ with its receptor present on keratinocytes (Orel et al. 1997).

Molecular mechanisms supporting constitutive expression of HSPA1 in normal keratinocytes are not known, and available data did not confirm the central role of HSF1 transcription factor. Although NHEK and $\mathrm{HaCaT}$ cells contain significant levels of HSF1 (Zhou et al. 1998; Nakamura et al. 2010), shRNA-mediated knockdown of HSF1 expression in $\mathrm{HaCaT}$ cells neither reduced HSPA1 expression, nor affected cell proliferation and viability (Nakamura et al. 2010). Additionally, it seems that some cell-specific mechanisms can control HSF1 functionality in skin cells. While overexpression of oncogenic RAS mutant (H-RasV12) in HaCaT cells induced nuclear translocation of transcriptionally competent HSF1 trimers, in contrast, repression of HSF1 activity could be observed in DFs (Zamkova et al. 2013). Based on the observation that basal level of HSPA1 was higher in keratinocytes from $\mathrm{p} 53$ deficient than from p53-proficient mice, one can assume that p53 may act as a negative regulator the HSPA1 gene expression in the epidermis (Quenneville et al. 2002).

\section{Expression of HSPA1 in keratinocytes after exposure to HS or UV stress treatment}

Constitutive expression of HSPA1 in keratinocytes is thought to maintain their constant readiness to rapidly respond to various environmental stresses including heat and UV light. Though, the significant induction of the HSPA1 gene expression in response to HS was demonstrated in NHEKs (Maytin et al. 1990, 1994; Schmidt-Rose et al. 1999; Parat et al. 1998; Hintzsche et al. 2012; Ramirez et al. 2015), HaCaT cells (Kao et al. 2016), human skin explants (Muramatsu et al. 1992), and in locally heated human skin areas in vivo (Wilson et al. 2000). HS-induced activation of the HSPAl gene expression, in contrast to its basal activity in non-stressed keratinocytes, was found to be HSF1-dependent (Zhou et al. 1998). A study of the global transcriptional response of human keratinocytes to $\mathrm{HS}\left(44^{\circ} \mathrm{C}, 40 \mathrm{~min}\right)$ revealed different kinetics of various HSPs induction. For example, the expression of HSPA 1 raised already at $4 \mathrm{~h}$ after HS, while the maximal levels of HSPB1 occurred $20 \mathrm{~h}$ later (Echchgadda et al. 2013). Because higher levels of HSPA1 were present in keratinocytes isolated from young (17-35 years old) than from elderly (65-90 years old) individuals, it seems that in keratinocytes, the stress response can be modulated by some age-related factors (Chinnathambi et al. 2008).

While the skin can be subjected to mild HS relatively often, its contact with a very high temperature occurs occasionally, either accidentally or during medical procedures. The expression of HSPA1 in NHEK can be induced even by a brief $(1 \mathrm{~s})$ severe HS $\left(50-60{ }^{\circ} \mathrm{C}\right)$ generated by laser pulse. Most NHEK survived temperature $60^{\circ} \mathrm{C}$ for as short a time as $1 \mathrm{~s}$, or $55^{\circ} \mathrm{C}$ for $30 \mathrm{~s}$, notably the consecutive short heat pulses induced thermotolerance (Bowman et al. 1997). Interestingly, HSPA1 level in epidermal keratinocytes can be also elevated by cold shock, as revealed by analysis of biopsies taken from human skin areas cooled to $15{ }^{\circ} \mathrm{C}$ for $2 \mathrm{~h}$ (Holland et al. 1993). Similarly, HSPA1 expression also increased in human skin explants incubated overnight at $4{ }^{\circ} \mathrm{C}$ (Jeanmaire et al. 2003).

One of the reasons for studying HSPA1 in skin was to assess its potential role in counteracting the harmful effects of phototoxicity generated by UV irradiation. It was shown that exposure of hairless mice (De la Coba et al. 2009) or keratinocytes (mouse, human) grown in standard 2D in vitro or 3D organotypic culture (Brunet and Giacomoni 1989; Jeanmaire et al. 2003; Perluigi et al. 2010; Yoshihisa et al. 2012; Wang et al. 2013; Kleszczyński et al. 2015) to UVB or UVA/UVB at various doses and experimental settings increased the levels of HSPA1 expression. However, Roh et al. (2008) observed no additional upregulation of HSPA1 after UVB or UVA irradiation in NHEK, A431 (epidermoid carcinoma) cells, while significant induction was found in DFs, in which basal level of HSPA1 is very low. 
The levels of HSPA1 induction in UV-treated keratinocytes can be modulated by UV protective filters. In a study performed on hairless mice (Skr: hr-1), two potential photoprotector molecules (porfirin-334 and shinorine) isolated from red alga Porphyra rosengurttii were tested. UV irradiation caused rapid but transient increase of HSPA1 in keratinocytes and dermal cells in the skin of unprotected mice. In contrast, apical application of porfirin-334 plus shinorine resulted in delayed, gradual, and prolonged elevation of HSPA1 levels after UV exposure (De la Coba et al. 2009). The pattern of HSPA1 expression after UV irradiation can be also affected by psoralen, the drug frequently used in treatment of psoriasis and vitiligo. The study performed on skin explants taken from healthy volunteers shown that the combined treatment with UVA and methoxypsoralen induced translocation of HSPA1 into the nuclei of keratinocytes, while no such an effect was observed if explants were treated separately (Muramatsu et al. 1993).

Several lines of evidence point to elevated level of HSPA1, as to the key factor mediating adaptive response of keratinocytes to UV irradiation. This conviction comes partially from the studies demonstrating that keratinocytes in vitro (Maytin et al. 1993, 1994) and in vivo (Kane and Mayytin 1995; Trautinger et al. 1996) as well as A431 cancer cells in vitro when pretreated with HS become more resistant to UV irradiation (Trautinger et al. 1995b; Merwald et al. 2006). Similarly, keratinocytes resistance to UVB irradiation increased following treatment with HSPA1 inducers such as prostaglandin J2 (15dPGJ2, 1-2 ng/ml) (Merwald et al. 2006) or alkanin, an active constituent from the root extract of Alkanna tinctoria of the Boraginaceae family (Yoshihisa et al. 2012). Cytoprotective action of HSPA1 against UVBinduced toxicity and inflammatory response was demonstrated in studies performed using transgenic mice and murine PAM212 cells constitutively overexpressing the human HSPA1 protein (Matsuda et al. 2010). In contrast, targeting HSPA1 expression either with antisense oligonucleotides (Trautinger et al. 1995b) or by microinjection of anti-HSPA1 antibody (Bayerl and Jung 1999) sensitized keratinocytes to UVB-induced death. Interestingly, the study of Kleszczyński et al. (2015) shown that the need for protective activity of HSPA1 in UV-irradiated keratinocytes can be alleviated by melatonin, a hormone having strong antioxidative capacity. The authors found that melatonin can significantly reduce HSPA1 induction in full-thickness artificial skin irradiated with UV.

The strong evidence supporting cytoprotective activity of HSPA1 in epidermal keratinocytes was provided by transgenic mice models. While the appearance of the skin in wild-type (wt) and HSPA1 knock-out mice was similar, a massive dying of keratinocytes in the basal layer of epidermis was detected 12 and $24 \mathrm{~h}$ after the UVB irradiation $\left(500 \mathrm{~mJ} / \mathrm{cm}^{2}\right)$ in HSPA1 knockout, but not in wt mice. At $24 \mathrm{~h}$ after irradiation, the entire epidermis of HSPA1 null mice was necrotic. The authors suggest that the lack of HSPA1 had a major negative impact of the DNA repair process (Kwon et al. 2002). Furthermore, keratinocytes of transgenic mice ectopically overexpressing the HSPA1 protein under the control of a constitutive $\beta$-actin promoter showed increased resistance to UVinduced apoptosis and contained decreased level of $8-\mathrm{OHdG}$ and pyrimidine dimers, both approved markers of DNA damage (Matsuda et al. 2010). It has to be noted, however, that transient accumulation of HSPA 1 in keratinocytes and dermal cells in response to UV irradiation did not render cells in irradiated skin areas resistant to UV-induced damage (De la Coba et al. 2009).

\section{Modulators of HSPA1 expression gene other than HS and UV irradiation}

Keratinocytes can overexpress HSPA1 in response to multiple toxic factors. Among them are, e.g., Ni compounds (Carroll and Wood 2000), fluorine (Prado et al. 2011), zinc-chelator $N, N, N^{\prime}, N^{\prime}$-tetrakis(2-pyridinylmethyl)-1,2-ethanediamin (Parat et al. 1998), antibacterial zinc pyrithione, a DNAdamaging drug (Lamore et al. 2010), $\mathrm{HgCl}_{2}$ (Jeanmaire et al. 2003), ectoine, an osmoprotectant derived from Halomonas elongata (Buommino et al. 2005), SDS, a skin irritant (Niwa et al. 2009), prostaglandin $\Delta^{12}-\mathrm{PGJ}_{2}$ (Ikai et al. 1992), or sorbitol at concentration inducing osmotic stress (Garmyn et al. 2001). The increased levels of HSPA1 were also reported in keratinocytes stably transfected with HPV16 E6/E7 oncoproteins (Liao et al. 2005). As it was mentioned above, HSPA1 expression in the epidermis can be reduced by nontoxic drugs such as melatonin (Kleszczyński et al. 2015).

\section{HSPA1 expression in the skin exposed to thermal laser irradiation}

In general, lasers through converting light into heat are used in dermatology in order to obtain selective photothermolysis of skin areas to initiate its remodeling. Which fragment of the skin is mostly affected depends on the length of laser light, targeted chromophore (essentially hemoglobin, water and melanin), beam power, and parameters of the treatment modality used. Non-ablative treatment induces thermolysis of dermis as well as lower epidermal strata leaving stratum corneum essentially intact, while ablative treatment damages the whole epidermis and the subcutaneous layer of the skin as well. The size of the wounded area depends of the methodology used. In fractional photothermolysis, multiple microscopic laser beams create vertical ablated channels, so called microthermal/microtreatment necrotic zones (MTZ) leaving undamaged tissues between them (rev in: Paasch 2016). The studies performed so far revealed that the level of HSPA1 increases in the epidermis surrounding the skin area damaged 
by thermolysis both in the case of ablative and non-ablative treatment. The maximal increment was observed between $4 \mathrm{~h}$ and 3 days post-treatment depending on the experimental schedule. Of note, no particular role of this effect in wound healing and re-epithelization was pointed out (Laubach et al. 2006; Hantash et al. 2007; Helbig and Paasch 2011; Sajjadi et al. 2013).

Results of studies on the effect of laser-mediated skin heating without causing thermolysis showed a possible involvement of HSPA1 in the re-epithelializaton process. In hairless rats, such a laser treatment increased the level of HspA1 in the irradiated skin (Souil et al. 2001), specifically in keratinocytes of stratum spinosum and stratum basale, and improved the process of wound healing (Capon et al. 2001). Further research in murine models, including HspA1 knockout mice, confirmed that laser-assisted pre-heating of the skin triggering HspA1 overproduction ameliorated the wound healing process (Wilmink et al. 2008; Makowski et al. 2012). Importantly, recent observation made in women 1 year after breast reduction showed that laser irradiation designed to trigger HSP synthesis in surgical incisions improved quality and cosmetic appearance of postsurgical scars (Casanova et al. 2017).

As a comment to the data mentioned above, one has to keep in mind that the heat shock response is a universal phenomenon, which takes place both in dermal and epidermal cells. Thus, without further in-depth studies, it is not possible to assess the extent to which both constitutive and laserinduced expression of HSPA1 in keratinocytes contributes to the healing of wounded skin. It has to be also added that so far, there is no data on whether keratinocytic HSPA1 has any role in the process known as photobiomodulation in which amelioration of wound healing results from non-thermal light treatment (Mosca et al. 2019). Such treatment known also as low-level light/laser therapy was shown to promote proliferation and maturation of keratinocytes (Sperandio et al. 2015); thus, involvement of HSPs cannot be excluded. We believe that the issue of laser- and/or light-induced modulation of the HSPs expression in keratinocytes needs further study since this problem appears important in the context of possible biostimulation in the treatment of chronic wounds.

\section{Extracellular HSPA1 (eHSPA1) as an immunomodulatory factor}

Keratinocytes spontaneously release high levels of eHSPA1 to extracellular milieu. Although such a behavior is not unique to keratinocytes, these somatic cells can release much more eHSPA1 than any of the other ones, and the basal secretion rate can be raised by irradiation with UVB (Wang et al. 2011) or laser-diode (Sokolovskii et al. 2014). Secretion of eHSPA1 was also observed following treatment of $\mathrm{HaCaT}$ and $\mathrm{A} 431$ cells with U73122, an inhibitor of phospholipase C (Evdonin et al. 2004, 2006). Multiple studies specify eHSPA1 as a danger signal that induces immune responses. In this context, it is crucial that keratinocytes have an ability not only to secrete but also bind and internalize eHSPA1 and HSPA1-peptide complexes. The uptake of eHSPA1 into keratinocytes, the rate of which can be enhanced by some pro-inflammatory mediators (TNF $\alpha$, IL-27, HMGB1), is mediated in an autocrine manner via low-density lipoprotein receptor-related protein-1 (LRP-1)/CD91 receptor (Wang et al. 2011). It is noteworthy that some reports denied presence of LRP-1/CD91 receptor on keratinocytes in healthy epidermis (Curry et al. 2003; Boyman et al. 2005). Because increased levels of eHSPA1 were found in cutaneous inflammatory pathologies such as psoriasis (Boehncke et al. 1994; Curry et al. 2003; Boyman et al. 2005; Gamal el Din et al. 2010), LE (Ghoreishi 2000; Mišunová et al. 2017; Jacquemin et al. 2017), and AD (Ghoreishi et al. 2000), this protein has been implicated in pathophysiology of these diseases.

Examination of human psoriatic lesion, as well as grafts of pre-psoriatic human skin (able to spontaneously develop into psoriatic lesions), onto immunocompromised mice revealed that HSPA 1 accumulates in keratinocytes in the close vicinity of immune cells, in particular dendritic cells expressing the LRP-1/CD91 receptor. It was thus proposed that eHSPA1 released from psoriatic keratinocytes, via interacting with LRP1/CD91 receptor present on dendritic cells, can activate proinflammatory responses (Boyman et al. 2005). The HSPA1overexpressing keratinocytes were also detected in LE and vitiligo lesions close to the areas infiltrated with plasmocytoid dendritic cells. In this context, it is important to mention that exogenous recombinant HSPA1 can stimulate the cultured dendritic cells via binding to the Lox-1 receptor. This interaction was sufficient to stimulate the uptake the CpG type A oligonucleotides into dendritic cells and induce the production of INF- $\alpha$. This cytokine in turn can activate expression of CXCL9/10 genes coding for chemokines attracting CD8(+) $T$ cells (Jacquemin et al. 2017). Importantly, it has been recently found that topical application of a cream containing high concentration of inducible HSPA derived from alfalfa plant (Medicago sativa) onto murine skin reduced skin inflammation in experimental psoriatic-like lesions induced by imiquimol (Seifarth et al. 2018).

Findings showing that HSPA1 is located at the dermoepidermal junction in the non-lesional skin of LE patients (Villalobos-Hurtado et al. 2003) lead to suggestion that HSPA1 itself can be an autoantigen and/or can participate in transferring SLE-related autoantigens to dermo-epidermal junctions. Recent studies showed that HSPA1 can be induced to significantly higher levels by UVB irradiation in keratinocytes from non-lesional skin of SLE patients than in keratinocytes from healthy donors. Therefore, it has been hypothesized that severe environmental stressors (e.g. UVB) via increased production and release of eHSPA 1 from 
keratinocytes may have profound effect on SLE development in predisposed individuals (Jacquemin et al. 2017). It is likely that eHSPA1 as a danger signal could activate dendritic cells to produce type I interferon, a cytokine involved in various cutaneous inflammatory and autoimmune disorders. Interestingly, an association between the polymorphic changes in HSPA1 locus with predisposition to SLE was reported (Fürnrohr et al. 2010).

One of pro-inflammatory factors involved in the development of AD is thymic stromal lymphopoietin (TSLP), an IL-7like chemokine/cytokine produced by keratinocytes. The release of TSLP was found to be suppressed in $\mathrm{HaCaT}$ cells exposed to HS or in keratinocytes incubated with exogenous recombinant HSPA1. This inhibitory action of HSPA1 on TSLP secretion was mediated by inhibition of NF- $K B$ activation. These observations suggested that exaggerated secretion of eHSPA1 from keratinocytes could be a potential component of AD therapy (Kao et al. 2016).

\section{Essentials about the HSPA2 protein}

The HSPA2 chaperone of HSPA family was first identified in rats and mice as being abundantly expressed in pachytene spermatocytes (Zakeri et al. 1988; Krawczyk et al. 1988; Wisniewski et al. 1990) and subsequently described as a testis-specific protein critical for mouse spermatogenesis (Dix et al. 1996). The human HSPA2 gene shows high similarity (approx. 92\% and 98\% at nucleotide and amino acids levels, respectively) to its rodent counterparts (Bonnycastle et al. 1994). Transcriptional and IHC analyses revealed that HSPA2 in rodents and more prominently in humans, beside male meiotic cells, is also expressed in certain somatic tissues (Bonnycastle et al. 1994; Scieglinska et al. 1997; Vydra et al. 2009; Scieglinska et al. 2011). High levels of HSPA2 in humans were confined among others to brain and stratified epithelia covering skin and esophagus, as well as pseudostratified epithelia lining bronchus (Scieglinska et al. 2011). Moreover, HSPA2 was also detected in numerous primary malignancies (Scieglinska et al. 2014). However, a significance of HSPA2 for cancer diagnosis, prognosis, or treatment has to be determined.

The mechanisms controlling the human HSPA2 gene expression are poorly understood. It is clear that HSPA2 is a representative of non-heat-inducible HSPA genes (for review see: Scieglinska and Krawczyk 2015); its transcription is under direct control of hypoxia inducible factor 1 (HIF-1) (Huang et al. 2009; Habryka et al. 2015), through binding to the hypoxia response element in the HSPA2 gene promoter (Habryka et al. 2015). Interestingly, HIF-1 in relation to the HSPA2 gene seems to act as a transcriptional activator in cancer cells, but as a repressor in keratinocytes (Habryka et al. 2015). The role of HSPA2 is best recognized in the context of its contribution to spermatogenesis and fertilization, but poorly characterized in somatic cells (reviewed in Nixon et al. 2017; Scieglinska and Krawczyk 2015). Up to now, only general chaperoning and cytoprotective properties of HSPA2 were demonstrated in vitro in cells overexpressing the human protein (Hageman et al. 2011; Filipczak et al. 2012).

\section{Expression and function of HSPA2 in epidermal keratinocytes}

IHC studies revealed that HSPA2 is present in the human skin in the cytoplasm and nuclei of keratinocytes located selectively in the basal layer (Scieglinska et al. 2011; GoglerPigłowska et al. 2018). Thus, HSPA2 in the epidermis showed the unique expression pattern, entirely distinct from that described previously for HSPB1 or HSPA1. Fluorescence activated cell sorting (FACS) of live NHEK according to their differentiation status followed by semi-quantitative analysis of mRNAs encoding HSPA2 and differentiation markers showed lowest level of HSPA2 transcripts in NHEK fraction enriched in quiescent progenitors/stem cells (GoglerPigłowska et al. 2018).

Results of shRNA-mediated knockdown of HSPA2 expression in $\mathrm{HaCaT}$ cells suggest that this chaperone neither protects the cells against HS-induced cytotoxicity, nor supports their proliferation. HSPA2-deficient $\mathrm{HaCaT}$ cells showed, however, reduced clone-forming ability, delay in spreading onto collagen IV, and reduced adhesiveness to fibronectin- or collagen IV-coated surfaces. These features of HSPA2-deficient keratinocytes classify them as representing more mature phenotype. The results of RHE model analysis led us to conclude that HSPA2 can contribute to mechanisms which restrain keratinocytes from premature entry into the terminal differentiation process (Gogler-Pigłowska et al. 2018). These observations suggest that HSPA2 can participate in controlling keratinocyte fate decision in the basal layer of epidermis.

Results of several studies pointed out that expression patterns (and possibly some functions) of HSPA2 in murine and human skin can be distinct. Analysis of transgenic mice bearing GFP reporter gene under the control of the promoter of the rat HSPA2 gene showed the presence of the reporter protein in cells of the hair bulbs (Vydra et al. 2009). In another study, the endogenous HSPA2 was located in suprabasal cells of the inner root sheath (Gunnarsson et al. 2016). Taking into account that skin alterations were not noticed in young HSPA2 knockout mice (Dix et al. 1996), one might speculate that the influence of HSPA2 on the maintenance of epidermal homeostasis in murine skin may be subtle or may change/enhance with aging. 


\section{Essentials about HSPC1 (HSP90a) and HSPC3 (HSP90ß) proteins}

HSPC1 and HSPC 3 are chaperone proteins of $90 \mathrm{kDa}$ molecular weight, which together with HSPC4 (GRP94) and HSPC5 (TRAP-1) proteins group into the HSPC (HSP90) family. In mammals, HSPC1 and HSPC 3 are two homologous isoforms sharing approx. $86 \%$ of aa sequence similarity; they are encoded by HSPC1 (HSP9OAA1), and HSPC 3 (HSP90AB1) genes, respectively (Sreedhar et al. 2004). The basal levels of both isoforms may reach up to $2 \%$ of total cytosolic proteins and can be doubled under cellular stress due to induction of the HSPC1 expression. Under physiological conditions, HSPC3 is expressed constitutively at significantly higher basal level than the stress-inducible HSPC1 (Zuehlke et al. 2005). HSPC1 and HSPC3 isoforms as multifunctional chaperones are engaged in activation, conformational stabilization, and final maturation of multiple cellular proteins; thus, it performs key functions in the maintenance of cellular proteostasis, being considered as a hub in the network of molecular chaperones (Eckl and Richter 2013; Röhl et al. 2013; Karagöz and Rudiger 2015). So far, about 700 substrates of HSPC (referred to as its "clients") have been characterized, which comprise proteins of various functional groups such as transcription factors, kinases, ubiquitin ligases, receptors, and others (Miyata et al. 2013). Following the discovery of the first effective HSPC inhibitor, namely antibiotic geldanamycin (GA), the development and testing in clinical trials of multiple HSPC-targeting drugs has been started (Tatokoro et al. 2015).

\section{Expression pattern and function of HSPC in keratinocytes}

Compared to other organs, the endogenous expression of HSPC in the skin is rather low, and the protein level is lower in the epidermis than in the dermis (Wilson et al. 2000; Kakeda et al. 2014; Tukaj et al. 2013). The usage of isoform-specific antibodies revealed that HSPC1 is present preferentially in the epidermis, whereas HSPC 3 in the dermis (Cheng et al. 2008). Increased expression of HSPC, mainly the HSPC1 isoform, was observed in psoriatic keratinocytes (Boehncke et al. 1994; Kakeda et al. 2014). Elevated expression of HSPC was also found in epidermal keratinocytes in perilesional skin areas in patients with bullous pemphigoid (BP) (Tukaj et al. 2013).

Under physiological conditions, HSPC1 is located in the cytoplasm and partially in the nuclei of keratinocytes, while a minor fraction of the protein is present extracellularly. However, HSPC1 can be efficiently secreted in a HIF- $1 \alpha-$ dependent manner from keratinocytes in hypoxic microenvironment of wounded skin (Woodley et al. 2009). Importantly, hypoxia promotes migration of human keratinocytes (O'Toole et al. 1997) and DFs (Li et al. 2007), a critical phenomenon in re-epithelialization process during skin wound healing. Intracellular level of HSPC and the rate of its release from keratinocytes are sensitive to cytokines present in the serum, e.g., to transforming growth factor-alpha (TGF $\alpha$ ), which causes secretion of HSPC1 via exosome pathway (Cheng et al. 2008). A study performed on HaCaT cells exposed to serum of bullous pemphigoid (BP) patients indicated that the secretion of HSPC from keratinocytes can be inhibited by BP autoantibodies, but not by control $\mathrm{IgG}$ from healthy donors (Tukaj et al. 2013). Importantly, blockade of HSPC activity by geldanamycin derivative $17-D M A G$ reverted BP autoantibodies-mediated pro-inflammatory response of keratinocytes (Tukaj et al. 2014). Since contribution of HSPC to other autoimmune blistering dermatoses including epidermolysis bullosa acquisita and possibly dermatitis herpetiformis was also found, more universal roles of HSPC as a pathophysiological factor and potential target for treatment of autoimmune BP diseases have been suggested (Tukaj et al. 2015).

A number of studies were aimed at determining the role of HSPC in regulating keratinocytes migration during wound healing. Skin injury (wound or burn) initiates the complex, multistep healing process that includes inflammation, tissue formation through re-epithelialization, angiogenesis and matrix protein production, and finally tissue remodeling. The closure of human wounds is largely mediated by re-epithelialization, a process accompanied by acquisition of highly active keratinocyte phenotype, characterized by continuous proliferation and high migratory properties (Rittie 2016). The pool of extracellular HSPC1 (eHSPC1) plays an essential role in switching to this phenotype (Woodley et al. 2009), while HSPC3 was found important for keratinocytes viability (Zou et al. 2017). A model explaining the role of HSPC1 in the reepithelialization postulates that wounding, via hypoxia and HIF- $1 \alpha$-dependent signaling, stimulates secretion of eHSPC1 from laterally migrating keratinocytes. Subsequent binding of eHSPC1 to low-density lipoprotein receptorrelated protein-1 (LRP-1) receptor present in keratinocytes stimulates, in an autocrine loop, keratinocyte migration for re-epithelialization (Woodley et al. 2009, 2015). Further studies showed that the LRP-1/CD91-mediated pro-migratory signaling is critically dependent on AKT1 and AKT2 activity (Tsen et al. 2013). eHSPC1 can also participate in inducing migration of DFs and microvascular endothelial cells (HDMECs), thus enabling fibroplasia and neovascularization ( $\mathrm{Li}$ et al. 2007). Although the detailed mechanism has not been established yet, it is known that eHSPC1, after reaching a critical threshold concentration, can override the inhibitory effect of TGF $\beta 3$ on DFs and HDMECs migration (Cheng et al. 2008).

The role of eHSPC1 in stimulating keratinocytes migration was also demonstrated on murine (Zhang et al. 2014) and pig 
models (O'Brien et al. 2014). Studies in nude mice showed that repeated local application of human recombinant HSPC1 onto the wounded dorsal region accelerated wound closure at approx. 30\% (Li et al. 2007). Consistently, topical application of HSPC1 in the early stage of a deep second-degree burn wounds in murine skin led to reduced inflammation and increased tissue granulation, with a concomitant reduction in the size of the wound (Zhang et al. 2014). The examination of deletion mutants of HSPC1 provides evidence that the nonchaperone function of this protein is essential during wound closure. The pro-motility action could be exerted by both the short 115 aa fragment of HSPC1 molecule (F-5 peptide) and HSPC1- $\Delta$ variant deficient in 232-amino acid from the carboxyl terminus, which was unable to dimerize and function as an intracellular chaperone (Cheng et al. 2011; O'Brien et al. 2014; Bhatia et al. 2016, 2018). When it comes to F-5 peptide, its application to wounded skin significantly improved healing of acute and diabetic wound in mice (Cheng et al. 2011), as well as in diabetic pig (O'Brien et al. 2014). Topical application of F-5 also effectively promoted healing of experimental burn wounds in pigs (Bhatia et al. 2016). Moreover, transfection of the human umbilical cord mesenchymal stem cells (hUC-MSCs) with the construct encoding F-5 improved survival of skin flaps subjected to ischemia-reperfusion experiment (Leng et al. 2017). In respect to transgenic mice bearing the chaperone-defective HSPC1- $\Delta$ mutant, the rate of wound closure was similar as in the wild-type HSPC1 mice. Importantly, selective inhibition of the eHSPC1- $\Delta$ protein by a monoclonal antibody disturbed normal wound closure in both wild-type HSPC1 and HSPC1- $\Delta$ mice (Bhatia et al. 2018). Pro-motility action of eHSPC1 can be considered a universal property of this chaperone since it was found critical for the invasiveness of cancer cells (Wong and Jay 2016). A more extensive information on the role of eHSPC1 in wound healing can be found in the recent review article (Guo et al. 2017).

A potential role of HSPC in regulating epidermal homeostasis is suggested by only a limited number of data. HSPC inhibition by 17-AAG (a geldanamycin derivative) in $\mathrm{HaCaT}$ cells blocked calcium-induced differentiation. This observation suggests that HSPC can contribute to early stages of keratinocyte differentiation (Miyoshi et al. 2012). The expression of HSPC was also found sensitive to disruption of skin barrier caused by tape stripping of stratum corneum (Dickel et al. 2010). The increased level of HSPC was also suggested to promote development of UV-B-induced cutaneous squamous cell carcinogenesis (Singh et al. 2015). Analysis of nude mice chronically ( 3 times per week for 25 weeks) exposed to UV light showed that local application of 17-AAG before each irradiation resulted in abnormalities such as high epidermal hyperplasia. At molecular level, this response was associated with reduced interaction of $\mathrm{HSPC} 3$ with $\mathrm{PKC} \varepsilon$, and decreased expression of pSTAT3 and pAKT. Epidermal abnormalities were also observed during embryogenesis in mutant mice lacking p23, a HSPC co-chaperone (MadonSimon et al. 2017).

\section{Summary and final conclusions}

Epidermis and keratinocytes are highly valuable models for investigating the complexity in expression and function of various HSPs. The current knowledge of molecular and cellular mechanisms underlying the processes of epidermal stratification and re-epithelialization gives opportunity to expand our understanding of HSPs involvement in the maintenance and restoration of homeostasis in adult tissue. The spatial and functional stratification of keratinocytes in the epidermis also facilitates the study of cytoprotective mechanisms in the context of tissue predisposed to frequent contact with multiple environmental stressors. Technical improvements, in particular development of three-dimensional human skin equivalents for in vitro assays, in combination with possibility of genetic manipulations of cutaneous cells enable the investigation of a particular gene in tissue formation, epidermal cells differentiation, phenotypic reprogramming, and death of keratinocytes.

In spite of above-mentioned achievements, knowledge of the importance of HSPs in epidermal differentiation, wound healing, development of keratinocytic carcinoma, and noncancerous skin diseases, as well as in cytoprotection against harmful environmental factors, is still far from being satisfactory. One of highly relevant issues, which is still not sufficiently explained in the functional context, is stratum-specific expression of HSPB1 and HSPA2 chaperones, for which no convincing confirmation of their cytoprotective role in keratinocytes has been provided. Different spatial localization of these two proteins in the epidermis seems to reflect their distinct contribution to keratinocyte differentiation. HSPA2 was shown to prevent the basal keratinocytes from premature entry into terminal differentiation process, while HSPB1 plays a role during the final steps of keratinization and formation of epidermal barrier. There is no doubt that intensive work has to be done in order to fully determine function of these chaperone proteins in the biology of epidermis.

In contrast, stress-inducible HSPA1 is nonselective for epidermal strata, shows no relationship with keratinocyte differentiation, but it can ensure quick and effective protection against various environmental stressors. Taking into account that HSPA1 can be secreted from keratinocytes, the further research on the impact of eHSPA1 in pathophysiology of inflammatory skin disorders deserves special attention.

With regard to HSPC proteins, it seems particularly important to notice differential expression of HSPC1 and HSPC3 isoforms in the normal and pathological skin. Although there are some hints that HSPC can participate in early steps of keratinocyte differentiation, the most firmly accepted 
knowledge concerns the regulatory role of eHSPC1 in keratinocyte and DFs migration during wound healing.

In summary, the studies performed so far indicate that HSPB1, HSPA1, HSPA2, and HSPC in keratinocytes contribute both to the maintenance of epidermal homeostasis as well as to skin pathophysiology, although the molecular mechanisms behind these functions are poorly understood. Thus, it seems justified to intensify studies aimed at determining how changes in HSPs expression, alterations in their posttranslational modifications, or secretion rate would influence the skin homeostasis and impact on etiopathogenesis of cutaneous diseases. Such knowledge would be highly valuable for better understanding and treatment of skin diseases and wound healing.

Funding information The current work was funded by National Science Centre, Poland, grant number 2017/25/B/NZ4/01550.

\section{Compliance with ethical standards}

Conflict of interest The authors declare that they have no conflict of interest.

Open Access This article is distributed under the terms of the Creative Commons Attribution 4.0 International License (http:// creativecommons.org/licenses/by/4.0/), which permits unrestricted use, distribution, and reproduction in any medium, provided you give appropriate credit to the original author(s) and the source, provide a link to the Creative Commons license, and indicate if changes were made.

\section{References}

Alcolea MP, Jones PH (2014) Lineage analysis of epidermal stem cells. Cold Spring Harb Perspect Med 4:a015206

Arrigo AP (2013) Human small heat shock proteins: protein interactomes of homo- and hetero-oligomeric complexes: an update. FEBS Lett 587:1959-1969

Arrigo AP (2017) Mammalian HspB1 (Hsp27) is a molecular sensor linked to the physiology and environment of the cell. Cell Stress Chaperones 22:517-529

Arrigo AP, Ducasse C (2002) Expression of the anti-apoptotic protein Hsp27 during both the keratinocyte differentiation and dedifferentiation of $\mathrm{HaCaT}$ cells: expression linked to changes in intracellular protein organization? Exp Gerontol 37:1247-1255

Bayerl C, Jung EG (1999) Microinjection of an antibody against HSP 72 in keratinocytes to study acute UV injury. Exp Dermatol 8:247-253

Becker B, Vogt T, Landthaler L, Stolz W (2001) Detection of differentially regulated genes in keratinocytes by cDNA array hybridization: Hsp27 and other novel players in response to artificial ultraviolet radiation. J Invest Dermatol 116:893-988

Besgen P, Trommler P, Vollmer S, Pronz JC (2010) Ezrin, Maspin, peroxiredoxin 2, and heat sock protein 27: potential targets of a Streptococcal-induced autoimmune response in psoriasis. J Immunol 184:5392-5402

Bhatia A, O'Brien K, Chen M, Wong A, Garner W, Woodley DT, Li W (2016) Dual therapeutic functions of F-5 fragment in burn wounds: preventing wound progression and promoting wound healing in pigs. Mol Ther Methods Clin Dev 3:16041
Bhatia A, O’Brien K, Guo J, Lincoln V, Kajiwara C, Chen M, Woodley DT, Udono H, Li W (2018) Extracellular and non-chaperone function of heat shock protein-90 alpha (HSP90 $\alpha$ ) is required for skin wound healing. J Invest Dermatol 138:423-433

Black AT, Hayden PJ, Casillas RP, Heck DE, Gerecke DR, Sinko PJ, Laskin DL, Laskin JD (2011) Regulation of Hsp27 and Hsp70 expression in human and mouse skin construct models by caveolae following exposure to the model sulfur mustard vesicant, 2chloroethyl ethyl sulfide. Toxicol Appl Pharmacol 253:112-120

Boehncke WH, Dahlke A, Zollner TM, Sterry W (1994) Differential expression of heat shock protein 70 (HSP70) and heat shock cognate protein 70 (HSC70) in human epidermis. Arch Dermatol Res 287: $68-71$

Bonnycastle LL, Yu CE, Hunt CR, Trask BJ, Clancy KP, Weber JL, Patterson D, Schellenberg GD (1994) Cloning, sequencing, and mapping of the human chromosome 14 heat shock protein gene (HSPA2). Genomics 23:85-93

Bowman PD, Schuschereba ST, Lawlor DF, Gilligan GR, Mata JR, DeBaere DR (1997) Survival of human epidermal keratinocytes after short-duration high temperature: synthesis of HSP70 and IL8. Am J Phys 272:C1988-C1994

Boxman IL, Kempenaar J, de Haas E, Ponec M (2002a) Induction of HSP27 nuclear immunoreactivity during stress is modulated by vitamin C. Exp Dermatol 11:509-517

Boxman ILA, Hensbergen PJ, Van der Schors RC, Bruynzeel DP, Tensen CP, Ponec M (2002b) Proteomic analysis of skin irritation reveals the induction of HSP27 by sodium lauryl sulphate in human skin. $\mathrm{Br}$ J Dermatol 146:777-785

Boyman O, Conrad C, Dudli C, Kielhorn E, Nickoloff BJ, Nestle FO (2005) Activation of dendritic antigen-presenting cells expressing common heat shock protein receptor CD91 during induction of psoriasis. Br J Dermatol 152:1211-1218

Brunet S, Giacomoni PU (1989) Heat shock mRNA in mouse epidermis after UV irradiation. Mutat Res 219:217-224

Bryantsev AL, Kurchashova SY, Golyshev SA, Polyakov VY, Wunderink HF, Kanon B, Budagova KR, Kabakov AE, Kampinga HH (2007) Regulation of stress-induced intracellular sorting and chaperone function of Hsp27 (HSPB1) in mammalian cells. Biochem J 407:407-417

Buommino E, Schiraldi C, Baroni A, Paoletti I, Lamberti M, De Rosa M, Tufano AT (2005) Ectoine from halophilic microorganisms induces the expression of hsp70 and hsp70B' inhuman keratinocytes modulating the proinflammatory response. Cell Stress Chaperones 10: 197-303

Calderwood SK (2018) Heat shock proteins and cancer: intracellular chaperones or extracellular signalling ligands? Philos Trans R Soc Lond Ser B Biol Sci 373(1738). https://doi.org/10.1098/rstb.2016. 0524

Calderwood SK, Gong J, Murshid A (2016) Extracellular HSPs: the complicated roles of extracellular HSPs in immunity. Front Immunol 7:159

Capon A, Souil E, Gauthier B, Sumian C, Bachelet M, Buys B, Polla BS, Mordon S (2001) Laser-assisted skin closure (LASC) by using a 815-nm diode-laser system accelerates and improves wound healing. Lasers Surg Med 28:168-175

Carroll S, Wood EJ (2000) Exposure of human keratinocytes and fibroblasts in vitro to nickel sulphate ions induces synthesis of stress protein Hsp72 and Hsp90. Acta Derm Venerol 80:94-97

Casanova D, Alliez A, Baptista C, Gonelli D, Lemdjadi Z, Bohbot S (2017) A 1- year follow-up of post-operative scars after the use of a 1210-nm laser assisted skin healing (LASH) technology: a randomized controlled trial. Aesthet Plast Surg 41:938-948

Chen H, Li S, Meng T, Zhang L, Dai T, Xiang Q, Su Z, Zhang Q, Huang Y (2014) HSP27 as a biomarker for predicting skin irritation in human skin and reconstructed organotypic skin model. Toxicol Lett 226:124-231 
Cheng CF, Fan J, Fedesco M, Guan S, Li Y, Bandyopadhyay B, Bright AM, Yeryshalami D, Liang M, Chen M, Han YP, Woodley DT, Li $\mathrm{W}(2008)$ Transforming growth factor $\alpha$ (TGF $\alpha$ )-stimulated secretion of HSP90 $\alpha$ : using the receptor LRP-1/CD91 to promote human skin cell migration against a TGF $\beta$-rich environment during wound healing. Mol Cell Biol 28:3344-3358

Cheng CF, Sahu D, Tsen F, Zhao Z, Fan J, Kim R, Wang X, O'Brien K, Li Y, Kuang Y, Chen M, Woodley DT, Li W (2011) A fragment of secreted HSP90 $\alpha$ carries properties that enable it to accelerate effectively both acute and diabetic wound healing in mice. J Clin Invest 121:4348-4361

Chinnathambi S, Tomanek-Chalkley A, Bickenbach JR (2008) HSP70 and EndoG modulate cell death by heat in human skin keratinocytes in vitro. Cells Tissues Organs 187:131-140

Choi JH, Choi DK, Sohn KC, Kwak SS, Suk J, Lim JS, Shin I, Kim SW, Lee JH, Joe CO (2012) Absence of a human DnaJ protein hTid-1S correlates with aberrant actin cytoskeleton organization in lesional psoriatic skin. J Biol Chem 287:25954-25963

Chow AM, Mok P, Xiao D, Khalouei S, Brown IR (2010) Heteromeric complexes of heat shock protein 70 (HSP70) family members, including Hsp70B', in differentiated human neuronal cells. Cell Stress Chaperones 15:545-553

Crowe J, Aubareda A, McNamee K, Przybycien PM, Lu X, Williams RO, Bou-Gharios G, Saklatvala J, Dean JLE (2013) Heat shock protein B1-deficient mice display impaired wound healing. PLoS One 8: e77383

Curry JL, Qin JZ, Bonish B, Carrick R, Bacon P, Panella J, Robinson J, Nockoloff BJ (2003) Innate immune-related receptors in normal and psoriatic skin. Arch Pathol Lab Med 127:178-186

D'Orazio J, Jarrett S, Amaro-Ortiz A, Scott T (2013) UV radiation and the skin. Int J Mol Sci 14:12222-12248

De la Coba F, Aguilera J, de Galvez MV, Alvarez M, Gallego E, Figureroa FL, Herrera E (2009) Prevention of the ultraviolet effects on clinical and histopathological changes, as well as the heat shock protien-70 expression in mouse skin by topical application of algal UV-absorbing compounds. J Dermatol Sci 55:161-169

Deaton MA, Bowman PD, Jones GP, Powanda MC (1990) Stress protein synthesis in human keratinocytes treated with sodium arsenite, phenyldichoroarsine and nitrogen mustard. Fundam Appl Toxicol $14: 471-476$

Dickel H, Gambichler T, Kamphowe J, Altmeyer P, Skrygan M (2010) Standarized tape stripping prior to patch testing induces upregulation of HSP90, HSP70, IL-33, TNF- $\alpha$, and IL-8/CXCL8 mRNA: a new insights in to the involvement of "alarmins". Contact Dermatitis 63:215-222

Dix DJ, Allen JW, Collins BW, Mori C, Nakamura N, Poorman-Allen P, Goulding EH, Eddy EM (1996) Targeted gene disruption of Hsp702 results in failed meiosis, germ cell apoptosis, and male infertility. Proc Natl Acad Sci U S A 93:3264-3268

Doupe DP, Jones PH (2012) Interfollicular epidermal homeostasis: dicing with differentiation. Exp Dermatol 21:249-253

Duverger O, Morange M (2005) Heat shock protein 25 plays multiple roles during mouse skin development. Cell Stress Chaperones 10: 268-277

Duverger O, Paslaru L, Morange M (2004) HSP25 is involved in two steps of the differentiation of PAM212 keratinocytes. J Biol Chem 279:10252-10260

Echchgadda I, Roth CC, Cerna CZ, Wilmink GJ (2013) Temporal gene expression kinetics for human keratinocytes exposed to hyperthermic stress. Cells 2:224-243

Eckl JM, Richter K (2013) Functions of the HSP90 chaperone system: lifting client proteins to new heights. Int J Biochem Mol Biol 4:157165

Edwards MJ, Marks R, Dykes PJ, Merrett VR, Morgan HE, O'Donovan MR (1991) Heat shock proteins in cultured human keratinocytes and fibroblasts. J Invest Dermatol 96:392-396
Elsholz F, Harteneck C, Muller W, Friedland K (2014) Calcium-a central regulator of keratinocyte differentiation in health and disease. Eur J Dermatol 24:650-661

Evdonin AL, Guzhova IV, Margulis BA, Medvedeva ND (2004) Phospholipase C inhibitor U73122, stimulates release of HSP70 stress protein from A431 human carcinoma cells. Cancer Cell Int $4: 2$

Evdonin AL, Martynova MG, Bystrova OA, Guzhova IV, Marguylis BA, Medvedeva ND (2006) The release of Hsp70 from A431 carcinoma cells is mediated by secretory-like granules. Eur J Cell Biol 85:443455

Fenga C, Loreto C, Caltabiano C, Germano D (2000) Heat shock protein 27 is overexpressed in the skin of bitumen exposed workers. Early observations. Boll Soc Ital Biol Sper 76:81-86

Filipczak PT, Piglowski W, Glowala-Kosinska M, Krawczyk Z, Scieglinska D (2012) HSPA2 overexpression protects V79 fibroblasts against bortezomib-induced apoptosis. Biochem Cell Biol 90:224-231

Fürnrohr BG, Wach S, Kelly JA, Haslbeck M, Weber CK, Stach CM, Hueber AJ, Graef D, Spriewald BM, Manger K, Herrmann M, Kaufmn KM, Frank SG, Goodmon E, James JA, Schett G, Winkler TH, Harley JB, Voll RE (2010) Polymorphism in the Hsp70 gene Locus are genetically associated with systemic lupus erythematosus. Ann Reum Dis 69:1983-1989

Gamal el Din A, Saleh HM, Fattah NA, Maksoud A (2010) Immunohistochemical expression of heat shock protein 70 in psoriasis vulgaris. N Y Sci J 3:112-116

Gandour-Edwards R, McClaren M, Isseroff RR (1994) Immunolocalization of low molecular-weight stress protein HSP 27 in normal skin and common cutaneous lesions. Am J Dermatopathol 16:504-509

Garmyn M, Mammone T, Pupe A, Gan D, Declercq L, Maes D (2001) Human keratinocytes respond to osmotic stress by p38 map kinase regulated induction of HSP70 and HSP27. J Invest Dermatol 117: $1290-1295$

Ghoreishi M (2000) Heat shock proteins in the pathogenesis of inflammatory skin diseases. J Med Dent Sci 47:143-150

Ghoreishi M, Yokozeki H, Hua WM, Nishioka K (2000) Expression of $27 \mathrm{KD}, 65 \mathrm{KJD}$ and 72/73 KD heat shock protein in atopic dermatitis: comparison with those in normal skin and contact dermatitis. $\mathrm{J}$ Dermatol 27:370-379

Gogler-Pigłowska A, Klarzyńska K, Sojka DR, Habryka A, GłowalaKosińska M, Herok M, Kryj M, Halczok M, Krawczyk Z, Scieglinska D (2018) Novel role for the testis-enriched HSPA2 protein in regulating epidermal keratinocyte differentiation. J Cell Physiol 233:2629-2644

Gonzalez AC, Costa TF, Andrade ZA, Medrado AR (2016) Wound healing - a literature review. An Bras Dermatol 91:614-620

Gonzalez-Celeiro M, Zhang B, Hsu YC (2016) Fate by chance, not by choice: epidermal stem cells go live. Cell Stem Cell 19:8-10

Gunnarsson AP, Christensen R, Li J, Jensen UB (2016) Global gene expression and comparison between multiple populations in the mouse epidermis. Stem Cell Res 17:191-202

Guo J, Chang C, Li W (2017) The role of secreted heat shock protein-90 (Hsp90) in wound healing - how could it shape future therapeutics? Expert Rev Proteomics 14:665-675

Gutowska-Owsiak D, de La Serna JB, Fritzsche M, Naeem A, Podobas EI, Leeming M, Colin-York H, O'Shaughnessy R, Eggeling C, Ogg GS (2018) Orchestrated control of filaggrin-actin scaffolds underpins cornification. Cell Death Dis 9:412

Habryka A, Gogler-Pigłowska A, Sojka D, Kryj M, Krawczyk Z, Scieglinska D (2015) Cell type-dependent modulation of the gene encoding heat shock protein HSPA2 by hypoxia-inducible factor HIF-1: down-regulation in keratinocytes and up-regulation in HeLa cells. Biochim Biophys Acta 1849:1155-1169 
Hageman J, van Waarde MA, Zylicz A, Walerych D, Kampinga HH (2011) The diverse members of the mammalian HSP70 machine show distinct chaperone-like activities. Biochem J 435:127-142

Hantash BM, Bedi VP, Kapadia B, Rahman Z, Jiang K, Tanner H, Chan $\mathrm{KF}$, Zachary CB (2007) In vivo histological evaluation of a novel ablative fractional resurfacing device. Lasers Surg Med 39:96-107

Helbig D, Paasch U (2011) Molecular changes during skin aging and wound healing after fractional ablative photothermolysis. Skin Res Technol 17:119-128

Hilton GR, Lioe H, Stengel F, Baldwin AJ, Benesch JL (2013) Small heat-shock proteins: paramedics of the cell. Top Curr Chem 328:6998

Hintzsche H, Riese T, Stopper H (2012) Hyperthermia-induced micronucleus formation in a human keratinocyte cell line. Mutat Res 738739:71-74

Holland DB, Roberts SG, Wood EJ, Cunlife WJ (1993) Cold shock induces the synthesis of stress proteins in human keratinocytes. J Invest Dermatol 101:196-199

Huang L, Min JN, Masters S, Mivechi NF, Moskophidis D (2007) Insights into function and regulation of small heat shock protein 25 (HSP27) in a mouse model with targeted gene disruption. Genesis 45:487-501

Huang WJ, Xia LM, Zhu F, Huang B, Zhou C, Zhu HF, Wang B, Chen B, Lei P, Shen GX, De-An T (2009) Transcriptional upregulation of HSP70-2 by HIF-1 in cancer cells in response to hypoxia. Int $\mathrm{J}$ Cancer 124:298-305

Ikai K, Shimizu K, Furukawa F, Fukushima M (1992) Induction of 72-kD heat shock protein and cytoskeleton damage by cytotoxic prostaglandin delta 12-PGJ2 in transformed human epidermal cells in culture. J Invest Dermatol 98:890-894

Ishiwatari S, Suzuki T, Hitomi T, Yoshino T, Matsukuma S, Tsuji T (2007) Effects of methyl paraben on skin keratinocytes. J Appl Toxicol 27:1-9

Jacquemin C, Rambert J, Guillet S, Thiolat D, Boukhedouni N, Doutre MS, Darrigade AS, Ezzedine K, Blanco P, Taieb A, Boniface K, Seneschal J (2017) HSP70 potentiates interferon-alpha production by plasmocytoid dendritic cells: relevance for cutaneous lupus and vitiligo pathogenesis. Br J Dermatol 177:1367-1375

Jantschitsch C, Kindas-Mugge I, Metze D, Amann G, Micksche M, Trautinger F (1998) Expression of the small heat shock protein HSP 27 in developing human skin. Br J Dermatol 139:247-253

Jeanmaire C, Pauly G, Moser P, Danoux L, Bardey V, Moussou P (2003) What is the most suitable strategy for stress proteins in cosmetics? IFSCC Mag 6:221-226

Jonak C, Klosner G, Kokesch C, FOdinger D, HOnigsmann H, Trautinger F (2002) Subcorneal colocalization of the small heat shock protein, hsp27, with keratins and proteins of the cornified cell envelope. Br J Dermatol 147:13-19

Jonak C, Metze D, Traupe H, Happle R, König A, Trautinger F (2005) The expression of the $27-\mathrm{kd}$ heat shock protein in keratinization disorders: an immunohistological study. Hum Pathol 36:686-693

Jonak C, Klosner G, Trautinger F (2006) Heat shock proteins in the skin. Int J Cosmet Sci 28:233-241

Jonak C, Mildner M, Klosner G, Paulitschke V, Kunstfeld R, Pehamberger H, Tschachler E, Trautinger F (2011) The hsp27 kD heat shock protein and $\mathrm{p} 38$-MAPK signaling are required for regular epidermal differentiation. J Dermatol Sci 61:32-37

Kaigorodova EV, Bogatyuk MV (2014) Heat shock proteins as prognostic markers of cancer. Curr Cancer Drug Targets 14:713-726

Kakeda M, Arock M, Schlapbach C, Yawalker N (2014) Increased expression of heat shock protein 90 in keratinocytes and mast cells in patients with psoriasis. I Am Acad Dermatol 70:683-690

Kampinga HH, Garrido C (2012) HSPBs: small proteins with big implications in human disease. Int J Biochem Cell Biol 44:1706-1710

Kampinga HH, Hageman J, Vos MJ, Kubota H, Tanguay RM, Bruford EA, Cheetham ME, Chen B, Hightower LE (2009) Guidelines for the nomenclature of the human heat shock proteins. Cell Stress Chaperones 14:105-111

Kane KS, Mayytin EV (1995) Ultraviolet B-induced apoptosis of keratinocytes in murine skin is reduced by mild local huperthermia. J Invest Dermatol 104:62-67

Kao JK, Lee CH, Lee MS, Hsu CS, Tsa LY, Tsai YG, Shieh JJ, Yang RC (2016) Heat shock pretreatment reduces expression and release of TSLP from keratinocytes under Th2 environment. Pediatr Allergy Immunol 27:62-69

Karagöz GE, Rudiger SGD (2015) Hsp90 interaction with clients. Trends Biochem Sci 40:117-125

Keagle JN, Welch WJ, Young DM (2001) Expression of heat shock proteins in a linear rodent wound. Wound Repair Regen 9:378-385

Kim K, Park H, Lim KM (2015) Phototoxicity: its mechanism and animal alternative test methods. Toxicol Res 31:97-104

Kindas-Mugge I, Trautinger F (1994) Increased expression of the M(r) 27,000 heat shock protein (hsp27) in in vitro differentiated normal human keratinocytes. Cell Growth Differ 5:777-781

Kindas-Mugge I, Herbacek I, Jantschitsch C, Micksche M, Trautinger F (1996) Modification of growth and tumorigenicity in epidermal cell lines by DNA-mediated gene transfer of M(r) 27,000 heat shock protein (hsp27). Cell Growth Differ 7:1167-1174

Kiriyama MT, Oka M, Takehana M, Kobayashi S (2001) Expression of small heat shock protein 27 (HSP27) in mouse skin tumors induced by UVB-irradiation. Biol Pharm Bull 24:197-200

Kleszczyński K, Zwicker S, Tukaj S, Kasperkiewicz M, Zillikens D, Wolf R, Fischer TW (2015) Melatonin compensates silencing of heat shock protein 70 and suppresses ultraviolet radiation-induced inflammation in human skin ex vivo and cultured keratinocytes. J Pineal Res 58:117-126

Krawczyk Z, Mali P, Parvinen M (1988) Expression of a testis-specific hsp70 gene-related RNA in defined stages of rat seminiferous epithelium. J Cell Biol 107:1317-1323

Kwon SB, Young C, Kim DS, Choi HO, Kim KH, Chun JH, Eun HC, Park KC, Oh CK, Seo JS (2002) Impaired repair ability of hsp70.1 KO mouse after UVB irradiation. J Dermatol Sci 28:144-151

Lamore SD, Cabello CM, Wondrak GT (2010) The topical antimicrobial zinc pyrithione is a heat shock response inducer that causes DNA damage and PARP-dependent energy crisis in human skin cells. Cell Stress Chaperones 15:309-322

Laplante AF, Moulin V, Auger FA, Landry J, Li H, Morrow G, Tanguey RM, Germain L (1998) Expression of heat shock proteins in mouse skin during wound healing. J Histochem Cytochem 46:1291-1301

Laubach HJ, Tannous Z, Anderson RR, Manstein D (2006) Skin responses to fractional photothermolysis. Lasers Surg Med 38:142149

Leng X, Fan Y, Wang Y, Sun J, Cai X, Hu C, Ding X, Hu X, Chen Z (2017) Treatment of ischemia-reperfusion injury of the skin flap using human umbilical cord mesenchymal stem cells (hUC-MSCs) transfected with "F-5" gene. Med Sci Monit 23:2751-2764

Li W, Li Y, Guan S, Fan J, Cheng CF, Bright AM, Chinn C, Chen M, Woodley DT (2007) Extracellular heat shock protein $90 \alpha$ : linking hypoxia to skin cell motility and wound healing. EMBO J 26:12211233

Liao WJ, Fan PS, Fu M, Fan XL, Liu YF (2005) Increased expression of $70 \mathrm{kD}$ heat shock protein in cultured primary human keratinocytes induced by human papillomavirus 16 E6/E7 gene. Chin Med J 118: 2058-2062

Lindquist S, Craig EA (1988) The heat-shock proteins. Annu Rev Genet 22:631-677

Liu K, Yu D, Cho YY, Bode AM, Ma W, Yao K, Li S, Li J, Bowden GT, Dong Z, Dong Z (2013) Sunlight UV-induced skin cancer relies upon activation of the $\mathrm{p} 38 \alpha$ signaling pathway. Cancer Res 73: 2181-2188

Madon-Simon M, Grad I, Bayo P, Perez P, Picard D (2017) Defective glucocorticoid receptor signaling and keratinocyte-autonomous 
defects contribute to skin phenotype of mouse embryos lacking the HSP90 co-chaperone p23. PLoS One 12:e0190035

Makowski AJ, Davidson JM, Mahadevan-Jansen A, Jansen ED (2012) In vivo analysis of laser preconditioning in incisional wound healing of wild-type and HSP70 knockout mice with Raman spectroscopy. Lasers Surg Med 44:233-244

Malusecka E, Zborek A, Krzyzowska-Gruca S, Krawczyk Z (2006) Immunohistochemical detection of the inducible heat shock protein hsp70: a methodological study. J Histochem Cytochem 54:183-190

Mascré G, Dekoninck S, Drogat B, Youssef KK, Broheé S, Sotiropoulou PA, Simons BD, Blanpain C (2012) Distinct contribution of stem and progenitor cells to epidermal maintenance. Nature 489:257-262

Matsuda M, Hoshino T, Yamashita Y, Tanaka K, Maji D, Sato K, Adachi H, Sobue G, Ihn H, Funasaka Y, Mizushima T (2010) Prevention of UVB radiation-induced epidermal damage by expression of heat shock protein 70. J Biol Chem 285:5848-5858

Maytin EV, Wimberly JM, Anderson RR (1990) Thermotolerance and the heat shock response in normal human keratinocytes in culture. J Invest Dermatol 95:635-642

Maytin EV, Murphy LA, Merrill MA (1993) Hyperthermia induces resistance to ultraviolet light B in primary and immortalized epidermal keratinocytes. Cancer Res 53:4952-4959

Maytin EV, Wimberly JM, Kane KS (1994) Heat shock modulates UVBinduced cell death in human epidermal keratinocytes: evidence for a hyperthermia-inducible protective response. J Invest Dermatol 103: $547-553$

McClaren M, Isseroff RR (1994) Dynamic changes in intracellular localization and isoforms of the $27-\mathrm{kD}$ stress protein in human keratinocytes. J Invest Dermatol 102:375-381

Merwald H, Kokesch C, Klosner G, Matsui M, Trautinger F (2006) Induction of the 72-kilodalton heat shock protein and protection from ultraviolet B-induced cell death in human keratinocytes by repetitive exposure to heat shock or 15 -deoksy- $\Delta^{12,14}$-prostaglandin $\mathrm{J}_{2}$. Cell Stress Chaperones 1:81-88

Mišunová M, Svitálková T, Pleštilová L, Kryštufková O, Tegzová D, Svobodová R, Hušáková M, Tomčík $\mathrm{M}$, Bečvář R, Závada $\mathrm{J}$, Mann H, Kolesár L, Slavčev A, Vencovský J, Novota P (2017) Molecular markers of systemic autoimmune disorders: the expression of MHC-located HSP70 genes is significantly associated with autoimmunity development. Clin Exp Rheumatol 35:33-42

Miyata Y, Nakamoto H, Neckers L (2013) The therapeutic target Hsp90 and cancer hallmarks. Curr Pharm Des 19:347-365

Miyoshi S, Yamazaki S, Uchiumi A, Katagata Y (2012) The HSP90 inhibitor 17-AAG repress calcium-induced cytokeratin 1 and 10 expression in HaCaT keratinocytes. FEBS Open Bio 2:47-50

Mol MAE, van den Berg RM, Benschop HP (2008) Proteomic assessment of sulfur mustard-induced protein adducts and other protein modifications in human epidermal keratinocytes. Toxicol Appl Pharmacol 230:97-108

Monastirli A, Vourekas A, Badavanis G, Pasmatzi E, Sagriotis A, Drainas D, Pavlidou D, Georgiou S, Sakkis T, Mantagos S, Kourounis G, Varakis J, Stamatiou G, Tsambaos D (2005) Hsp27 expression coincides with epidermal stratification during human epidermal morphogenesis. Acta Derm Venereol 85:389-393

Morris SD (2002) Heat shock proteins and the skin. Clinical Exptl Dermatol 27:220-224

Mosca RC, Ong AA, Albasha O, Bass K, Arany P (2019) Photobiomodulation therapy for wound care: a potent, noninvasive, photoceutical approach. Adv Skin Wound Care 32:157-167

Multhoff G, Hightower LE (2011) Distinguishing integral and receptorbound heat shock protein 70 (Hsp70) on the cell surface by Hsp70specific antibodies. Cell Stress Chaperones 16:251-255

Muramatsu T, Tada H, Kobayashi N, Yamji M, Shirai T, Ohnishi T (1992) Induction of the $72-\mathrm{kD}$ heat shock protein in organ-cultured normal human skin. J Invest Dermatol 98:786-790
Muramatsu T, Yamashina Y, Tada H, Nelson CF, Greenhalgh DG (1993) 8-Methoxypsoralen plus UVA induces the $72 \mathrm{kDa}$ heat shock protein in organ-cultured normal human skin. Photochem Photobiol 58: 809-812

Murase D, Hachiya A, Fullenkamp R, Beck A, Moriwaki S, Hase T, Takema Y, Manga P (2016) Variation in Hsp70-1A expression contributes to skin color diversity. J Invest Dermatol 136:1681-1691

Nakamura Y, Fujimoto M, Hayashida N, Takii R, Nakai A, Muto M (2010) Silencing HSF1 by short hairpin RNA decreases cell proliferation and enhances sensitivity to hyperthermia in human melanoma cell lines. J Dermatol Sci 60:187-192

Niiyama S, Yoshino T, Matsukuma S, Mukai H (2016) Heat shock protein $27 \mathrm{kDa}$ content in stratum corneum correlates with severity of atopic dermatitis. Acta Derm Venerol 96:976-977

Niwa M, Nagai K, Oike H, Kobori M (2009) Evaluation of the skin irritation using a DNA microarray on a reconstructed human epidermal model. Biol Pharm Bull 32:203-208

Nixon B, Bromfield EG, Cui J, De Iuliis GN (2017) Heat shock protein A2 (HSPA2): regulatory roles in germ cell development and sperm function. Adv Anat Embryol Cell Biol 222:67-93

Nozaki J, Takehana M, Kobayashi S (1997) UVB Irradiation induces changes in cellular localization and phosphorylation of mouse HSP27. Photochem Photobiol 65:843-848

O'Brien K, Bhatia A, Tsen F, Chen M, Wong AK, Woodley DT, Li W (2014) Identification of the critical therapeutic entity in secreted HSP90 $\alpha$ that promotes wound healing in newly re-standardized healthy and diabetic pig models. PLoS One 9:e113956

Orel L, Simon MM, Karlseder J, Bhardway R, Trautinger F, Schwarz T, Luger TA (1997) $\alpha$-melanocyte stimulating hormone downregulates differentiation-driven heat shock protein 70 expression in keratinocytes. J Invest Dermatol 108:401-405

O'Shaughnessy RF, Welti JC, Cooke JC, Avilion AA, Monks B, Birnbaum MJ, Byrne C (2007) AKT-dependent HSP27 (Hsp27) activity in epidermal differentiation. J Biol Chem 282:17297-17305

O'Toole EA, Marinkovich MP, Peavey CL, Amieva MR, Furthmayr H, Mustoe TA, Woodley DT (1997) Hypoxia increases human keratinocyte motility on connective tissue. J Clin Invest 100:28812891

Paasch U (2016) The future of fractional lasers. Facial Plast Surg 32:261268

Palotai R, Szalay MS, Csermely P (2008) Chaperones as integrators of cellular networks: changes of cellular integrity in stress and diseases. IUBMB Life 60:10-18

Parat MO, Richard MJ, Favier A, Beani JC (1998) Metal chelator NNNNN-tetrakis-(2-pyridylmethyl)ethylene diamine inhibits the induction of heat shock protein 70 synthesis by heat in cultured keratinocytes. Biol Trace Elem Res 65:261-270

Pelham HR (1984) Hsp70 accelerates the recovery of nucleolar morphology after heat shock. EMBO J 3:3095-3100

Perluigi M, Di Domenico F, Blarzini C, Foppoli C, Civi C, Giorgi A, Grillo C, De Marco F, Butterfield DA, Schinina ME, Coccia R (2010) Effects of UVB-induced oxidative stress on protein expression and specific protein oxidation in normal human epithelial keratinocytes: a proteomic approach. Proteome Sci 8:13

Pockley AG, Henderson B, Multhoff G (2014) Extracellular cell stress proteins as biomarkers of human disease. Biochem Soc Trans 42: 1744-1751

Potten CS (1974) The epidermal proliferative unit: the possible role of the central basal cell. Cell Tissue Kinet 7:77-88

Prado E, Wurtz T, Ferbus D, Shabana EH, Forest N, Berdal A (2011) Sodium fluoride influences the expression of keratins in cultured keratinocytes. Cell Biol Toxicol 27:69-81

Quenneville LA, Trotter MJ, Maeda T, Tron VA (2002) p53-Dependent regulation of heat shock protein 72 . Br J Dermatol 146:786-791

Radons J (2016) The human HSP70 family of chaperones: where do we stand? Cell Stress Chaperones 21:379-404 
Ramirez VP, Stamatis M, Shmukler A, Aneskievich BJ (2015) Basal and stress-inducible expression of HSPA6 in human keratinocytes is regulated by negative and positive promoter regions. Cell Stress Chaperones 20:95-107

Rittie L (2016) Cellular mechanism of skin repair in humans and other mammals. J Cell Commun Signal 10:103-120

Robitaille H, Proulx R, Robitaille K, Blouin R, Germain L (2005) The mitogen-activated protein kinase kinase kinase dual leucine zipperbearing kinase (DLK) acts as a key regulator of keratinocyte terminal differentiation. J Biol Chem 280:12732-12741

Robitaille H, Simard-Bisson C, Larouche D, Tanguay RM, Blouin R, Germain L (2010) The small heat-shock protein Hsp27 undergoes ERK-dependent phosphorylation and redistribution to the cytoskeleton in response to dual leucine zipper-bearing kinase expression. $\mathrm{J}$ Invest Dermatol 130:74-85

Roh BH, Kim DH, Cho MK, Park YL, Whang KU (2008) Expression of heat shock protein 70 in human skin cells as a photoprotective function after UV exposure. Ann Dermatol 20:184-189

Röhl A, Rohrberg J, Buchgner J (2013) The chaperone Hsp90: changing partners for demanding clients. Trends Biochem Sci 38:253-262

Saibil H (2013) Chaperone machines for protein folding, unfolding and disaggregation. Nat Rev Mol Cell Biol 14:630-642

Sajjadi AY, Mitra K, Grace M (2013) Expression of heat shock proteins 70 and 47 in tissues following short pulse laser irradiation: assessment of thermal damage and healing. Med Eng Phys 35:1406-1414

Schmidt-Rose T, Pollet D, Will K, Bergemann J, Wittern KP (1999) Analysis of UV-B-induced DNA damage and its repair in heatshocked skin cells. J Photochem Pchotobiol 53:144-152

Scieglinska D, Krawczyk Z (2015) Expression, function, and regulation of the testis-enriched heat shock HSPA2 gene in rodents and humans. Cell Stress Chaperones 20:221-235

Scieglinska D, Widłak W, Rusin M, Markkula M, Krawczyk Z (1997) Expression of the testis-specific HSP70-related gene (hst70 gene) in somatic non-testicular rat tissues revealed by RT-PCR and transgenic mice analysis. Cell Biol Int 21:813-821

Scieglinska D, Piglowski W, Chekan M, Mazurek A, Krawczyk Z (2011) Differential expression of HSPA1 and HSPA2 proteins in human tissues; tissue microarray-based immunohistochemical study. Histochem Cell Biol 135:337-350

Scieglinska D, Gogler-Piglowska A, Butkiewicz D, Chekan M, Malusecka E, Harasim J, Habryka A, Krawczyk Z (2014) HSPA2 is expressed in human tumors and correlates with clinical features in non-small cell lung carcinoma patients. Anticancer Res 34:28332840

Seifarth FG, Lax JE, Harvey J, DiCorleto PE, Elaine Husni M, Chandrasekharan UM, Tytell M (2018) Topical heat shock protein 70 prevents imiquimod-induced psoriasis-like inflammation in mice. Cell Stress Chaperones 23:1129-1135

Senoo M (2013) Epidermal stem cells in homeostasis and wound repair of the skin. Adv Wound Care (New Rochelle) 2:273-282

Simard-Bisson C, Bidoggia J, Larouche D, Guérin SL, Blouin R, Hirai SI, Germain L (2017) A role for DLK in microtubule reorganization to the cell periphery and in the maintenance of desmosomal and tight junction integrity. J Invest Dermatol 137:132-141

Singh A, Singh A, Sand JM, Bauer SJ, Hafeez BB, Meske L, Verma AK (2015) Topically applied Hsp90 inhibitor 17AAG inhibits ultraviolet radiation-induced cutaneous squamous cell carcinogenesis. J Invest Dermatol 135:1098-1107

Sokolovskii GS, Onikienko SB, Zemlyanoi AV, Soboleva KK, Pikhtin NA, Tarasov IS, Guzova IV, Margulis BA (2014) Hsp70 and ceramide release by diode laser-treated mouse skin cells in vivo. J Phys Conf Ser 572:012017

Souil E, Capon A, Mordon S, Dinh-Xuan AT, Poll BS, Bachelet M (2001) Treatment with $815-\mathrm{nm}$ diode laser induces long-lasting expression of 72-kDa heat shock protein in normal rat skin. Br J Dermatol 144: 260-266
Sperandio FF, Simões A, Corrêa L, Aranha AC, Giudice FS, Hamblin MR, Sousa SC (2015) Low-level laser irradiation promotes the proliferation and maturation of keratinocytes during epithelial wound repair. J Biophotonics 8:795-780

Sreedhar AS, Kalmar E, Csermely P, Shen YF (2004) Hsp90 isoforms: functions, expression and clinical importance. FEBS Lett 562:11-15

Strachan LR, Ghadially R (2008) Tiers of clonal organization in the epidermis: the epidermal proliferation unit revisited. Stem Cell Rev 4:149-157

Sur R, Lyte PA, Southall MD (2008) Hsp27 regulates pro-inflammatory mediator release in keratinocytes by modulating NF-kappa B signaling. J Invest Dermatol 128:1116-1122

Tatokoro M, Koga F, Yoshida S, Kihara K (2015) Heat shock protein 90 targeting therapy: state of the art and future perspectives. EXCLI J 14:48-58

Tóth ME, Gombos I, Sántha M (2015) Heat shock proteins and their role in human diseases. Acta Biologica Szegediensis 59:121-141

Trautinger F, Trautinger I, Kindas-Mügge I, Metze D, Luger TA (1993) Human keratinocytes in vivo and in vitro constitutively express the $72 \mathrm{kD}$ heat shock protein. J Invest Dermatol 101:334-338

Trautinger F, Kindas-Mugge I, Dekrout B, Knobler RM, Metze D (1995a) Expression of the $27-\mathrm{kDa}$ heat shock protein in human epidermis and in epidermal neoplasms: an immunohistological study. Br J Dermatol 133:194-202

Trautinger F, Kindas-Mügge I, Barlan B, Neuner P, Knobler RM (1995b) $72-\mathrm{kD}$ heat shock protein is a mediator of resistance to ultraviolet light B. J Invest Dermatol 105:160-162

Trautinger F, Knobler RM, Hönigsmann H, Mayr W, Kindås-Mügge I (1996) Increased expression of the 72-kDa heat shock protein and reduced sunburn cell formation in human skin after local hyperthermia. J Invest Dermatol 107:442-443

Trautinger F, Kokesch C, Herbacek I, Knobler RM, Kindas-Mugge I (1997) Overexpression of the small heat shock protein hsp27, confers resistance to hyperthermia, but not to oxidative stress and UVinduced cell death, in a stably transfected cell carcinoma cell line. J Photochem Photobiol B 39:90-95

Treweek TM, Meehan S, Ecroyd H, Carver JA (2014) Small heat-shock proteins: important players in regulating cellular proteostasis. Cell Mol Life Sci 72:429-451

Tsen F, Bhatia A, O'Brien K, Cheng CF, Chen M, Hay N, Stiles B, Woodley DT, Li W (2013) Extracellular heat shock protein 90 signals through subdomain II and the NPVY motif of LRP-1 receptor to Akt1 and Akt2: a circuit essential for promoting skin cell migration in vitro and wound healing in vivo. Mol Cell Biol 33:49474959

Tukaj S, Kleszczynski K, Vafia K, Groth S, Meyserburg D, Trzonkowski P, Ludwig RL, Zillikens D, Schmidt E, Fischer TW, Kasperkiewicz M (2013) Aberrant expression and secretion of heat shock protein 90 in patients with Bullous pemphigoid. PLoS One 8:e70496

Tukaj S, Gruner D, Zilliekens D, Kasperkiewicz M (2014) Hsp90 blockade modulates bullous pemphigoid IgG-induced IL- 8 production by keratinocytes. Cell Stress Chaperones 19:887-894

Tukaj S, Zilliekens D, Kasperkiewicz M (2015) Heat shock protein 90: a pathophysiological factor and novel treatment target in autoimmune bullous skin diseases. Exp Dermatol 24:567-571

Valacchi G, van der Vliet A, Schock BC, Okamato T, Obermuller-Jevic U, Cross C.E, Packer L (2002) Ozone exposure activates oxidative stress responses in murine skin. Toxicology 179:163-170.

Valacchi G, Pagnin E, Okamoto T, Corbacho AM, Olano E, Davis PA, van der Vliet A, Packer L, Cross CE (2003) Induction of stress proteins and MMP-9 by $0.8 \mathrm{ppm}$ of ozone in murine skin. Biochem Biophys Res Commun 305:741-746

Vidal Magalhaes WV, Gouveia Nogueira MF, Kaneko TM (2012) Heat shock proteins (HSP): dermatological implications and perspectives. Eur J Dermatol 22:8-13 
Villalobos-Hurtado R, Sanchez-Rodriguez SH, Avalos-Diaz E, HerreraEsparza R (2003) Possible role of HSP70 in autoantigen shuttling to the dermo-epidermal junction in systemic lupus erythematosus. Reumatismo 55:155-158

Vydra N, Winiarski B, Rak-Raszewska A, Piglowski W, Mazurek A, Scieglinska D, Widlak W (2009) The expression pattern of the 70$\mathrm{kDa}$ heat shock protein Hspa2 in mouse tissues. Histochem Cell Biol 132:319-330

Wagstaff MJD, Shah M, McGrouther DA, Latchman DS (2007) The heats shock proteins and plastic surgery. J Plast Reconstr Aesthet Surg 60:947-982

Wakita H, Tokura Y, Furukawa F, Takigawa M (1994) High calcium induces heat shock proteins 72 and 60 in cultured human keratinocytes: comparative study with heat shock and sunlamp light irradiation. J Dermatol Sci 8:136-144

Wang D, Eiz-Vesper B, Jana Zeitvogel J, Dressel R, Werfel T, Wittmann M (2011) Human keratinocytes release high levels of inducible heat shock protein 70 that enhances peptide uptake. Exp Dermatol 20: 637-641

Wang XY, Tao CJ, Wu QY, Yuan CD (2013) Protein extract of ultravioletirradiated human skin keratinocytes promote the expression of mitogen-activated protein kinases, nuclear factor- $\mathrm{kB}$ and interferon regulatory factor-3 in Langerhans cells via Toll-like receptor 2 and 4. Photodermatol Photoimmunol Photomed 29:41-48

Wilmink GJ, Opalenik SR, Beckham JT, Mackanos MA, Nanney LB, Contag CH, Davidson JM, Jansen ED (2008) In-vivo optical imaging of hsp70 expression to assess collateral tissue damage associated with infrared laser ablation of skin. J Biomed Opt 13:054066

Wilson N, McArdle A, Guerin D, Tasker H, Wareing P, Foster CS, Jackson MJ, Rhodes LE (2000) Hyperthermia to normal human skin in vivo upregulates heat shock proteins $27,60,72 \mathrm{i}$ and 90 . J Cutan Pathol 27:176-182

Wisniewski J, Kordula T, Krawczyk Z (1990) Isolation and nucleotide sequence analysis of rat testis-specific major heat shock (hsp70)related gene. Biochim Biophys Acta 1048:93-99

Wong DS, Jay DG (2016) Emerging roles of extracellular Hsp90 in cancer. Adv Cancer Res 129:141-163

Wong JW, Shi B, Farboud B, McClaren M, Shibamoto T, Cross CE, Isseroff RR (2000) Ultraviolet B-mediated phosphorylation of the small heat shock protein HSP27 in human keratinocytes. J Invest Dermatol 115:427-434

Woodley DT, Fan J, Cheng CF, Li W, Chen M, Bu G, Li W (2009) Participation of the lipoprotein receptor LRP1 in hypoxia-HSP90 $\alpha$ autocrine signaling to promote keratinocyte migration. J Cell Sci 122:1495-1498

Woodley DT, Wysong A, DeClerk B, Chen M, Li W (2015) Keratinocyte migration and a hypothetical new role for extracellular heat shock protein 90 alpha in orchestrating skin wound heling. Adv Wound Care 4:203-212

Yoshihisa Y, Hassan MA, Furusawa Y, Tabuchi Y, Kondo T, Shimizu T (2012) Alkannin, HSP70 inducer, protects against UVB induced apoptosis in human keratinocytes. PLoS One 7:e47903

Yusuf N, Nasti TH, Ahmad I, Chowdhury S, Mohiuddin H, Xu H, Athar M, Timares L, Elmets CA (2015) In vivo suppression of HSP27 and HSP70 accelerates DMBA-induced skin carcinogenesis by inducing antigenic unresponsiveness to the initiating carcinogenic chemical. J Immunol 194:4796-4803

Zakeri ZF, Wolgemuth DJ, Hunt CR (1988) Identification and sequence analysis of a new member of the mouse HSP70 gene family and characterization of its unique cellular and developmental pattern of expression in the male germ line. Mol Cell Biol 8:2925-2932

Zamkova M, Khromova N, Kopnin BP, Kopnin P (2013) Ras-induced ROS upregulation affecting cell proliferation is connected with cell type-specific alterations of HSF1/SESN3/p21Cip1/WAF1 pathways. Cell Cycle 12:826-836

Zhang QH, Zhang L, Xiao X, Su ZJ, Zou P, Hu H, Huang YD, He QY (2010) Heavy metals chromium and neodymium reduced phosphorylation level of heat shock protein 27 in human keratinocytes. Toxicol in Vitro 24:1098-1104

Zhang QH, Dai TL, Zhang L, Zhang MJ, Xiao X, Hu H, Zou P, Liu X, Xiang Q, Su ZJ, Huang YD, He QY (2011) Identification of potential biomarkers for predicting acute dermal irritation by proteomic analysis. J Appl Toxicol 31:762-772

Zhang Y, Bai X, Wang Y, Li N, Li X, Han F, Su L, Hu D (2014) Role for heat shock protein 90 , in the proliferation and migration of $\mathrm{HaCaT}$ cells and in the deep second-degree burn wound healing in mice. PLoS One 9:e103723

Zhou X, Tron VA, Li G, Trotter MJ (1998) Heat shock transcription factor-1 regulates heat shock protein-72 expression in human keratinocytes exposed to ultraviolet B light. J Invest Dermatol 111: 194-198

Zou M, Bhatia A, Dong H, Jayaprakas P, Guo J, Sahu D, Hou Y, Tsen F, Tong C, O’Brien K, Situ AJ, Schmidt T, Chen M, Ying Q, Ulmer TS, Woodley DT, Li W (2017) Evolutionary conserved dual lysine motif determines the non-chaperone function of secreted HSP90alpha in tumor progression. Oncogene 36:2160-2171

Zuehlke AD, Beebe K, Neckers L, Prince T (2005) Regulation and function of the human HSP90AA1 gene. Gene 570:8-16

Publisher's note Springer Nature remains neutral with regard to jurisdictional claims in published maps and institutional affiliations. 